4

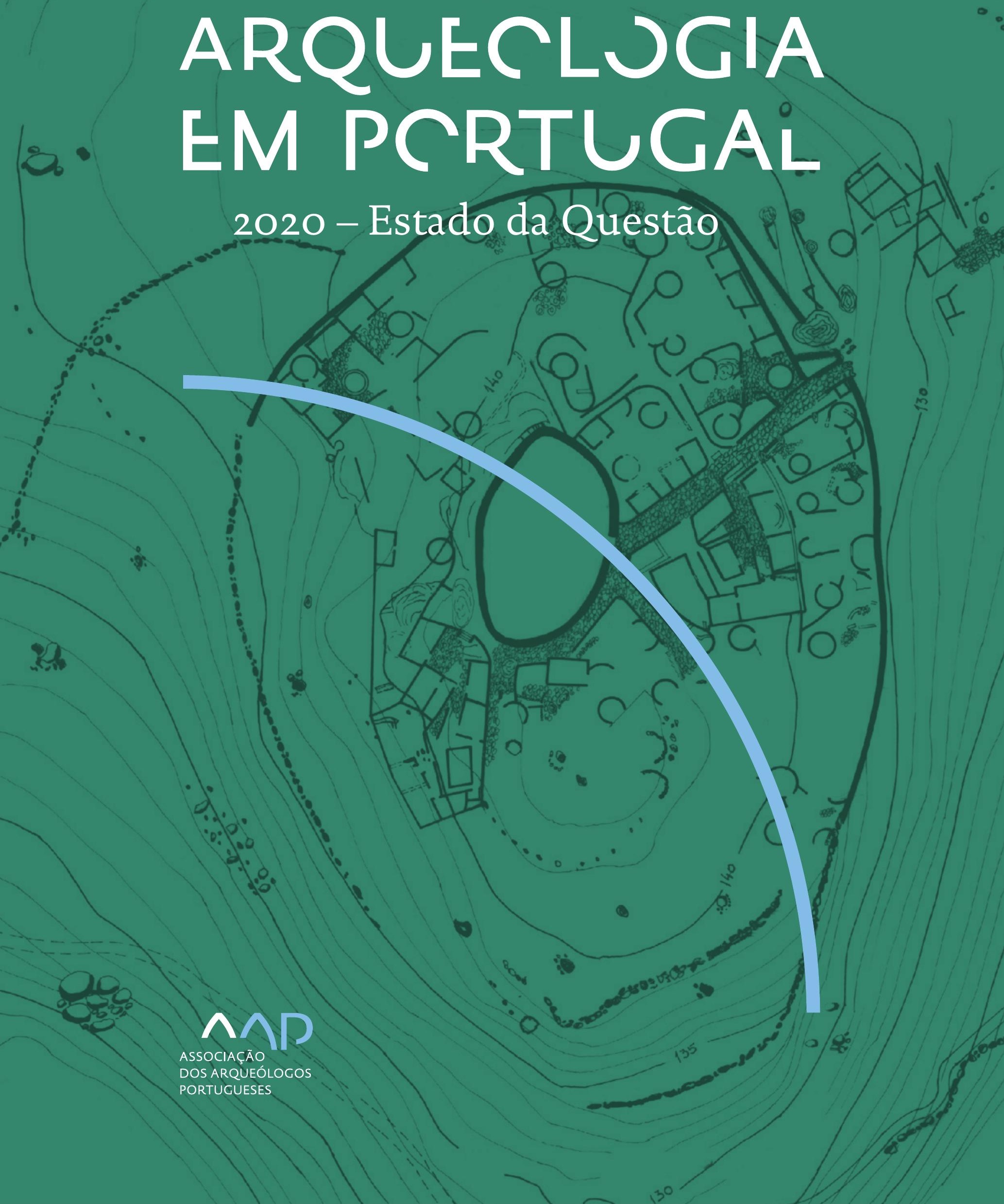


Coordenação editorial: José Morais Arnaud, César Neves e Andrea Martins Design gráfico: Flatland Design

AAP - ISBN: 978-972-9451-89-8

CITCEM - ISBN: 978-989-8970-25-1

Associação dos Arqueólogos Portugueses e CITCEM

Lisboa, 2020

O conteúdo dos artigos é da inteira responsabilidade dos autores. Sendo assim a Associação dos Arqueólogos Portugueses declina qualquer responsabilidade por eventuais equívocos ou questões de ordem ética e legal.

Desenho de capa:

Planta do castro de Monte Mozinho (Museu Municipal de Penafiel).

\section{$\hat{\wedge} \mathrm{P}$}

DOS ARQUEÓLOGOS PORTUGUESES

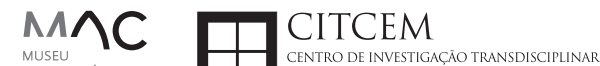
MUSEU
ARQUELLÓGICO
DO CARMO
U.PORTO

FLUP FACULDADE DE LETRAS
UNIVERSIDADE DO PORTO

Apoio

EC para a Ciência 


\section{Índice}

15 Prefácio

José Morais Arnaud

\section{Historiografia e Teoria}

17 Território, comunidade, memória e emoção: a contribuição da história da arqueologia (algumas primeiras e breves reflexões)

Ana Cristina Martins

25 Como descolonizar a arqueologia portuguesa?

Rui Gomes Coelho

41 Arqueologia e Modernidade: uma revisitação pessoal e breve de alguns aspetos da obra homónima de Julian Thomas de 2004

Vítor Oliveira Jorge

57 Dados para a História das Mulheres na Arqueologia portuguesa, dos finais do século XIX aos inícios do século XX: números, nomes e tabelas

Filipa Dimas / Mariana Diniz

73 Retractos da arqueologia portuguesa na imprensa: (in)visibilidades no feminino

Catarina Costeira / Elsa Luís

85 Arqueologia e Arqueólogos no Norte de Portugal Jacinta Bugalhão

101 Vieira Guimarães (1864-1939) e a arqueologia em Tomar: uma abordagem sobre o território e as gentes

João Amendoeira Peixoto / Ana Cristina Martins

115 Os memoráveis? A arqueologia algarvia na imprensa nacional e regional na presente centúria (2001-2019): características, visões do(s) passado(s) e a arqueologia

enquanto marca

Frederico Agosto / João Silva

129 A Evolução da Arqueologia Urbana e a Valorização Patrimonial no Barlavento Algarvio: Os casos de Portimão e Silves

Artur Mateus / Diogo Varandas / Rafael Boavida

\section{Gestão, Valorização e Salvaguarda do Património}

145 O Caderno Reivindicativo e as condições de trabalho em Arqueologia Miguel Rocha / Liliana Matias Carvalho / Regis Barbosa / Mauro Correia / Sara Simões / Jacinta Bugalhão / Sara Brito / Liliana Veríssimo Carvalho / Richard Peace / Pedro Peça / Cézer Santos

155 Os Estudos de Impacte Patrimonial como elemento para uma estratégia sustentável de minimização de impactes no âmbito de reconversões agrícolas Tiago do Pereiro

165 Salvaguarda de Património arqueológico em operações florestais: gestão e sensibilização Filipa Bragança / Gertrudes Zambujo / Sandra Lourenço / Belém Paiva / Carlos Banha / Frederico Tatá Regala / Helena Moura / Jacinta Bugalhão / João Marques / José Correia / Pedro Faria / Samuel Melro

179 Os valores do Património: uma investigação sobre os Sítios Pré-históricos de Arte Rupestre do Vale do Rio Côa e de Siega Verde José Paulo Francisco 
189 Conjugando recursos arqueológicos e naturais para potenciar as visitas ao Geoparque Litoral de Viana do Castelo (Noroeste de Portugal)

Hugo A. Sampaio / Ana M.S. Bettencourt / Susana Marinho / Ricardo Carvalhido

203 Áreas de Potencial Arqueológico na Região do Médio Tejo: Modelo Espacial Preditivo Rita Ferreira Anastácio / Ana Filipa Martins / Luiz Oosterbeek

223 Património Arqueológico e Gestão Territorial: O contributo da Arqueologia para a revisão do PDM de Avis

Ana Cristina Ribeiro

237 A coleção arqueológica do extinto Museu Municipal do Porto - Origens, Percursos e Estudos

Sónia Couto

251 Valpaços - uma nova carta arqueológica

Pedro Pereira / Maria de Fátima Casares Machado

263 Arqueologia na Cidade de Peniche

Adriano Constantino / Luís Rendeiro

273 Arqueologia Urbana: a cidade de Lagos como caso de Estudo Cátia Neto

285 Estratégias de promoção do património cultural subaquático nos Açores. O caso da ilha do Faial

José Luís Neto / José Bettencourt / Luís Borges / Pedro Parreira

297 Carta Arqueológica da Cidade Velha: Uma primeira abordagem

Jaylson Monteiro / Nireide Tavares / Sara da Veiga / Claudino Ramos / Edson Brito /

Carlos Carvalho / Francisco Moreira / Adalberto Tavares

311 Antropologia Virtual: novas metodologias para a análise morfológica e funcional Ricardo Miguel Godinho / Célia Gonçalves

\section{Didáctica da Arqueologia}

327 Como os projetos de Arqueologia podem contribuir para uma comunidade culturalmente mais consciente Alexandra Figueiredo / Claúdio Monteiro / Adolfo Silveira / Ricardo Lopes

337 Educação Patrimonial - Um cidadão esclarecido é um cidadão ativo! Ana Paula Almeida

351 A aproximação da Arqueologia à sala de aula: um caso de estudo no $3^{\circ}$ ciclo do Ensino Básico Luís Serrão Gil

363 Arqueologia 3.o - Pensar e comunicar a Arqueologia para um futuro sustentável Mónica Rolo

377 “Conversa de Arqueólogos" - Divulgar a Arqueologia em tempos de Pandemia Diogo Teixeira Dias

389 Escola Profissional de Arqueologia: desafios e oportunidades Susana Nunes / Dulcineia Pinto / Júlia Silva / Ana Mascarenhas

399 Os Museus de Arqueologia e os Jovens: a oferta educativa para o público adolescente Beatriz Correia Barata / Leonor Medeiros

411 O museu universitário como mediador entre a ciência e a sociedade: o exemplo da secção de arqueologia no Museu de História Natural e da Ciência da Universidade do Porto (MHNC-UP)

Rita Gaspar 
421 Museu de Lanifícios: Real Fábrica de Panos. Atividades no âmbito da Arqueologia Beatriz Correia Barata / Rita Salvado

427 Arqueologia Pública e o caso da localidade da Mata (Torres Novas) Cláudia Manso / Ana Rita Ferreira / Cristiana Ferreira / Vanessa Cardoso Antunes

431 Do sítio arqueológico ao museu: um percurso (também) didático Lídia Fernandes

447 Estão todos convidados para a Festa! E para dançar também... O projecto do Serviço Educativo do Museu Arqueológico do Carmo na $5^{\underline{a}}$ Edição da Festa da Arqueologia Rita Pires dos Santos

459 O “Clã de Carenque”, um projeto didático de arqueologia Eduardo Gonzalez Rocha

469 Mediação cultural: peixe que puxa carroça nas Ruínas Romanas de Troia Inês Vaz Pinto / Ana Patrícia Magalhães / Patrícia Brum / Filipa Santos

481 Didática Arqueológica, experiências do Projeto Mértola Vila Museu Maria de Fátima Palma / Clara Rodrigues / Susana Gómez / Lígia Rafael

\section{Arte Rupestre}

497 Os inventários de arte rupestre em Portugal Mila Simões de Abreu

513 O projeto FIRST-ART - conservação, documentação e gestão das primeiras manifestações de arte rupestre no Sudoeste da Península Ibérica: as grutas do Escoural e Maltravieso Sara Garcês / Hipólito Collado / José Julio García Arranz / Luiz Oosterbeek / António Carlos Silva / Pierluigi Rosina / Hugo Gomes / Anabela Borralheiro Pereira / George Nash / Esmeralda Gomes / Nelson Almeida / Carlos Carpetudo

523 Trabalhos de documentação de arte paleolítica realizados no âmbito do projeto PalæoCôa André Tomás Santos / António Fernando Barbosa / Luís Luís / Marcelo Silvestre / Thierry Aubry

537 Imagens fantasmagóricas, silhuetas elusivas: as figuras humanas na arte do Paleolítico Superior da região do Côa Mário Reis

$55^{1}$ Os motivos zoomórficos representados nas placas de tear de Vila Nova de São Pedro (Azambuja, Portugal) Andrea Martins / César Neves / José M. Arnaud / Mariana Diniz

571 Arte Rupestre do Monte de Góios (Lanhelas, Caminha). Síntese dos resultados dos trabalhos efectuados em 2007-2009 Mário Varela Gomes

599 Gravuras rupestres de barquiformes no Monte de S. Romão, Guimarães, Noroeste de Portugal Daniela Cardoso

613 Círculos segmentados gravados na Bacia do Rio Lima (Noroeste de Portugal): contributos para o seu estudo Diogo Marinho / Ana M.S. Bettencourt / Hugo Aluai Sampaio

631 Equídeos gravados no curso inferior do Rio Mouro, Monção (NW Portugal). Análise preliminar Coutinho, L.M. / Bettencourt, A.M.S / Sampaio, Hugo A.S

645 Paletas na Arte Rupestre do Noroeste de Portugal. Inventário preliminar Bruna Sousa Afonso / Ana M. S. Bettencourt / Hugo A. Sampaio 


\section{Pré-História}

661 O projeto Miño/Minho: balanço de quatro anos de trabalhos arqueológicos Sérgio Monteiro-Rodrigues / João Pedro Cunha-Ribeiro / Eduardo Méndez-Quintas / Carlos Ferreira / Pedro Xavier / José Meireles / Alberto Gomes / Manuel Santonja / Alfredo Pérez-González

677 A ocupação paleolítica da margem esquerda do Baixo Minho: a indústria lítica do sítio de Pedreiras 2 (Monção, Portugal) e a sua integração no contexto regional Carlos Ferreira / João Pedro Cunha-Ribeiro / Sérgio Monteiro-Rodrigues / Eduardo Méndez-Quintas / Pedro Xavier / José Meireles / Alberto Gomes / Manuel Santonja / Alfredo Pérez-González

693 O sítio acheulense do Plistocénico médio da Gruta da Aroeira Joan Daura / Montserrat Sanz / Filipa Rodrigues / Pedro Souto / João Zilhão

703 As sociedades neandertais no Barlavento algarvio: modelos preditivos com recurso aos SIG

Daniela Maio

715 A utilização de quartzo durante o Paleolítico Superior no território dos vales dos rios Vouga e Côa

Cristina Gameiro / Thierry Aubry / Bárbara Costa / Sérgio Gomes / Luís Luís / Carmen Manzano / André Tomás Santos

733 Uma perspetiva diacrónica da ocupação do concheiro do Cabeço da Amoreira (Muge, Portugal) a partir da tecnologia lítica Joana Belmiro / João Cascalheira / Célia Gonçalves

745 Novos dados sobre a Pré-história Antiga no concelho de Palmela. A intervenção arqueológica no sítio do Poceirão I

Michelle Teixeira Santos

757 Problemas em torno de Datas Absolutas Pré-Históricas no Norte do Alentejo Jorge de Oliveira

771 Povoamento pré-histórico nas áreas montanhosas do NO de Portugal: o Abrigo 1 de Vale de Cerdeira Pedro Xavier / José Meireles / Carlos Alves

783 Apreciação do povoamento do Neolítico Inicial na Baixa Bacia do Douro. A Lavra I (Serra da Aboboreira) como caso de estudo Maria de Jesus Sanches

797 O Processo de Neolitização na Plataforma do Mondego: os dados do Sector C do Outeiro dos Castelos de Beijós (Carregal do Sal)

João Carlos de Senna-Martinez / José Manuel Quintã Ventura / Andreia Carvalho / Cíntia Maurício

823 Novos trabalhos na Lapa da Bugalheira (Almonda, Torres Novas) Filipa Rodrigues / Pedro Souto / Artur Ferreira / Alexandre Varanda / Luís Gomes / Helena Gomes / João Zilhão

837 A pedra polida e afeiçoada do sítio do Neolítico médio da Moita do Ourives (Benavente, Portugal)

César Neves

857 Casal do Outeiro (Encarnação, Mafra): novos contributos para o conhecimento do povoamento do Neolítico final na Península de Lisboa.

Cátia Delicado / Carlos Maneira e Costa / Marta Miranda / Ana Catarina Sousa

873 Stresse infantil, morbilidade e mortalidade no sítio arqueológico do Neolítico Final/ Calcolítico ( $4^{\circ}$ e $3^{\circ}$ milénio a.C.) do Monte do Carrascal 2 (Ferreira do Alentejo, Beja) Liliana Matias de Carvalho / Sofia N. Wasterlain 
885 Come together: O Conjunto Megalítico das Motas (Monção, Viana do Castelo) e as expressões Campaniformes do Alto Minho Ana Catarina Basílio / Rui Ramos

899 Trabalhos arqueológicos no sítio Calcolítico da Pedreira do Poio Carla Magalhães / João Muralha / Mário Reis / António Batarda Fernandes

913 O sítio arqueológico de Castanheiro do Vento. Da arquitectura do sítio à arquitectura de um território João Muralha Cardoso

925 Estudo zooarqueológico das faunas do Calcolítico final de Vila Nova de São Pedro (Azambuja, Portugal): Campanhas de 2017 e 2018 Cleia Detry / Ana Catarina Francisco / Mariana Diniz / Andrea Martins / César Neves / José Morais Arnaud

943 As faunas depositadas no Museu Arqueológico do Carmo provenientes de Vila Nova de São Pedro (Azambuja): as campanhas de 1937 a 1967 Ana Catarina Francisco / Cleia Detry / César Neves / Andrea Martins / Mariana Diniz / José Morais Arnaud

959 Análise funcional de material lítico em sílex do castro de Vila Nova de S. Pedro (Azambuja, Portugal): uma primeira abordagem Rafael Lima

971 O recinto da Folha do Ouro 1 (Serpa) no contexto dos recintos de fossos calcolíticos alentejanos

António Carlos Valera / Tiago do Pereiro / Pedro Valério / António M. Monge Soares

\section{Proto-História}

987 Produção de sal marinho na Idade do Bronze do noroeste Português. Alguns dados para uma reflexão

Ana M. S. Bettencourt / Sara Luz / Nuno Oliveira / Pedro P. Simões / Maria Isabel C. Alves / Emílio Abad-Vidal

1001 A estátua-menir do Pedrão ou de São Bartolomeu do Mar (Esposende, noroeste de Portugal) no contexto arqueológico da fachada costeira de entre os rios Neiva e Cávado Ana M. S. Bettencourt / Manuel Santos-Estévez / Pedro Pimenta Simões / Luís Gonçalves

1015 O Castro do Muro (Vandoma/Baltar, Paredes) - notas para uma biografia de ocupação da Idade do Bronze à Idade Média

Maria Antónia D. Silva / Ana M. S. Bettencourt / António Manuel S. P. Silva / Natália Félix

1031 Do Bronze Final à Idade Média - continuidades e hiatos na ocupação de Povoados em Oliveira de Azeméis João Tiago Tavares / Adriaan de Man

1041 As faunas do final da Idade do Bronze no Sul de Portugal: leituras desde o Outeiro do Circo (Beja)

Nelson J. Almeida / Íris Dias / Cleia Detry / Eduardo Porfírio / Miguel Serra

1055 A Espada do Monte das Oliveiras (Serpa) - uma arma do Bronze Pleno do Sudoeste Rui M. G. Monge Soares / Pedro Valério / Mariana Nabais / António M. Monge Soares

1065 São Julião da Branca (Albergaria-a-Velha) - Investigação e valorização de um povoado do Bronze Final

António Manuel S. P. Silva / Paulo A. P. Lemos / Sara Almeida e Silva / Edite Martins de Sá

1083 Do castro de S. João ao Mosteiro de Santa Clara: notícia de uma intervenção arqueológica, em Vila do Conde Rui Pinheiro 
1095 O castro de Ovil (Espinho), um quarto de século de investigação - resultados e questões em aberto

Jorge Fernando Salvador / António Manuel S. P. Silva

1111 O Castro de Salreu (Estarreja), um povoado proto-histórico no litoral do Entre Douro e Vouga

Sara Almeida e Silva / António Manuel S. P. Silva / Paulo A. P. Lemos / Edite Martins de Sá

1127 Castro de Nossa Senhora das Necessidades (Sernancelhe): uma primeira análise artefactual Telma Susana O. Ribeiro

${ }_{1141}$ A cividade de Bagunte. O estado atual da investigação Pedro Brochado de Almeida

1153 Zoomorfos na cerâmica da Idade do Ferro no NW Peninsular: inventário, cronologias e significado Nuno Oliveira / Cristina Seoane

1163 Vasos gregos em Portugal: diferentes maneiras de contar a história do intercâmbio cultural na Idade do Ferro

Daniela Ferreira

1175 Os exotica da necrópole da Idade do Ferro do Olival do Senhor dos Mártires (Alcácer do Sal) no seu contexto regional

Francisco B. Gomes

\section{Antiguidade Clássica e Tardia}

1191 O uso de madeira como combustível no sítio da Quinta de Crestelos (Baixo Sabor): da Idade do Ferro à Romanização Filipe Vaz / João Tereso / Sérgio Simões Pereira / José Sastre / Javier Larrazabal Galarza / Susana Cosme / José António Pereira / Israel Espi

1207 Cultivos de Época Romana no Baixo Sabor: continuidade em tempos de mudança? João Pedro Tereso / Sérgio Simões Pereira / Filipe Santos / Luís Seabra / Filipe Vaz

1221 A casa romana na Hispânia: aplicação dos modelos itálicos nas províncias ibéricas Fernanda Magalhães / Diego Machado / Manuela Martins

1235 As pinturas murais romanas da Rua General Sousa Machado, n. ${ }^{5}$ 1, Chaves José Carvalho

1243 Trás do Castelo (Vale de Mir, Pegarinhos, Alijó) - Uma exploração agrícola romana do Douro

Tony Silvino / Pedro Pereira

1255 A sequência de ocupação no quadrante sudeste de Bracara Augusta: as transformações de uma unidade doméstica Lara Fernandes / Manuela Martins

1263 Os Mosaicos com decoração geométrica e geométrico-vegetalista dos sítios arqueológicos da área do Conuentus Bracaraugustanus. Novas abordagens quanto à conservação, restauro, decoração e datação Maria de Fátima Abraços / Licínia Wrench

1277 “Casa Romana” do Castro de São Domingos (Cristelos, Lousada): Escavação, Estudo e Musealização Paulo André de P. Lemos

1291 A arqueobotânica no Castro de Guifões (Matosinhos, Noroeste de Portugal): O primeiro estudo carpológico

Luís Seabra / Andreia Arezes / Catarina Magalhães / José Varela / João Pedro Tereso 
1305 Um Horreum Augustano na Foz do Douro (Monte do Castelo de Gaia, Vila Nova de Gaia) Rui Ramos

1311 Ponderais romanos na Lusitânia: padrões, formas, materiais e contextos de utilização Diego Barrios Rodríguez

1323 Um almofariz centro-itálico na foz do Mondego

Marco Penajoia

1335 Estruturas romanas de Carnide - Lisboa Luísa Batalha / Mário Monteiro / Guilherme Cardoso

1347 O contexto funerário do sector da "necrópole NO" da Rua das Portas de S. Antão (Lisboa): o espaço, os artefactos, os indivíduos e a sua interconectividade na interpretação do passado Sílvia Loja, José Carlos Quaresma, Nelson Cabaço, Marina Lourenço, Sílvia Casimiro, Rodrigo Banha da Silva, Francisca Alves-Cardoso

${ }_{1361}$ Povoamento em época Romana na Amadora - resultados de um projeto pluridisciplinar Gisela Encarnação / Vanessa Dias

1371 A Arquitectura Residencial em Mirobriga (Santiago do Cacém): contributo a partir de um estudo de caso Filipe Sousa / Catarina Felício

${ }_{1385}$ O fim do ciclo. Saneamento e gestão de resíduos nos edifícios termais de Mirobriga (Santiago do Cacém)

Catarina Felício / Filipe Sousa

1399 Balsa, Topografia e Urbanismo de uma Cidade Portuária Vítor Silva Dias / João Pedro Bernardes / Celso Candeias / Cristina Tété Garcia

1413 No Largo das Mouras Velhas em Faro (2017): novas evidências da necrópole norte de Ossonoba e da sua ocupação medieval Ricardo Costeira da Silva / Paulo Botelho / Fernando Santos / Liliana Nunes

1429 Instrumentos de pesca recuperados numa fábrica de salga em Ossonoba (Faro) Inês Rasteiro / Ricardo Costeira da Silva / Paulo Botelho

1439 A Necrópole Romana do Eirô, Duas Igrejas (Penafiel): intervenção arqueológica de 2016 Laura Sousa / Teresa Soeiro

1457 Ritual, descarte ou afetividade? A presença de Canis lupus familiaris na Necrópole Noroeste de Olisipo (Lisboa)

Beatriz Calapez Santos / Sofia Simões Pereira / Rodrigo Banha da Silva / Sílvia Casimiro / Cleia Detry / Francisca Alves Cardoso

1467 Dinâmicas económicas em Bracara na Antiguidade Tardia Diego Machado / Manuela Martins / Fernanda Magalhães / Natália Botica

1479 Cerâmicas e Vidros da Antiguidade Tardia do Edifício sob a Igreja do Bom Jesus (Vila Nova de Gaia) Joaquim Filipe Ramos

1493 Novos contributos para a topografia histórica de Mértola no período romano e na Antiguidade Tardia Virgílio Lopes

\section{8. Época Medieval}

1511 Cerâmicas islâmicas no Garb setentrional "português": algumas evidências e incógnitas Constança dos Santos / Helena Catarino / Susana Gómez / Maria José Gonçalves / Isabel Inácio / Gonçalo Lopes / Jacinta Bugalhão / Sandra Cavaco / Jaquelina Covaneiro / Isabel Cristina Fernandes / Ana Sofia Gomes 
1525 Contributo para o conhecimento da cosmética islâmica, em Silves, durante a Idade Média Rosa Varela Gomes

1537 Yábura e o seu território - uma análise histórico-arqueológica de Évora entre os séculos VIII-XII José Rui Santos

1547 A encosta sul do Castelo de Palmela - resultados preliminares da escavação arqueológica Luís Filipe Pereira / Michelle Teixeira Santos

1559 A igreja de São Lourenço (Mouraria, Lisboa): um conjunto de silos e de cerâmica medieval islâmica

Andreia Filipa Moreira Rodrigues

1571 O registo material de movimentações populacionais no Médio Tejo, durante os séculos XII-XIII. Dois casos de "sunken featured buildings", nos concelhos de Cartaxo e Torres Novas Marco Liberato / Helena Santos / Nuno Santos

1585 O nordeste transmontano nos alvores da Idade média. Notas para reflexão Ana Maria da Costa Oliveira

1601 Sepulturas escavadas na rocha do Norte de Portugal e do Vale do Douro: primeiros resultados do Projecto SER-NPVD

Mário Jorge Barroca / César Guedes / Andreia Arezes / Ana Maria Oliveira

1619 "Portucalem Castrum Novum" entre o Mediterrâneo e o Atlântico: o estudo dos materiais cerâmicos alto-medievais do arqueossítio da rua de D. Hugo, nํ. 5 (Porto) João Luís Veloso

1627 A Alta Idade Média na fronteira de Lafões: notas preliminares sobre a Arqueologia no Concelho de Vouzela

Manuel Luís Real / Catarina Tente

1641 Um conjunto cerâmico medieval fora de portas: um breve testemunho aveirense Susana Temudo

${ }_{1651}$ Os Lóios do Porto: uma perspetiva integrada no panorama funerário da Baixa Idade Média à Época Moderna em meios urbanos em Portugal

Ana Lema Seabra

1659 O Caminho Português Interior de Santiago como eixo viário na Idade Média Pedro Azevedo

1665 Morfologia Urbana: Um exercício em torno do Castelo de Ourém André Donas-Botto / Jaqueline Pereira

1677 Intervenção arqueológica na Rua Marquês de Pombal/Largo do Espírito Santo (Bucelas, Loures)

Florbela Estêvão / Nathalie Antunes-Ferreira / Dário Ramos Neves / Inês Lisboa

1691 O Cemitério Medieval do Poço do Borratém e a espacialidade funerária na cidade de Lisboa Inês Belém / Vanessa Filipe / Vasco Noronha Vieira / Sónia Ferro / Rodrigo Banha da Silva

1705 Um Espaço Funerário Conventual do séc. XV em Lisboa: o caso do Convento de São Domingos da Cidade Sérgio Pedroso / Sílvia Casimiro / Rodrigo Banha da Silva / Francisca Alves Cardoso

\section{9. Época Moderna e Contemporânea}

1721 Arqueologia Moderna em Portugal: algumas reflexões críticas em torno da quantificação de conjuntos cerâmicos e suas inferências históricas e antropológicas Rodrigo Banha da Silva / André Bargão / Sara da Cruz Ferreira

1733 Faianças de dois contextos entre os finais do século XVI e XVIII do Palácio dos Condes de Penafiel, Lisboa

Martim Lopes / Tomás Mesquita 
1747 Um perfil de consumo do século XVIII na foz do Tejo: O caso do Mercado da Ribeira, Lisboa Sara da Cruz Ferreira / Rodrigo Banha da Silva / André Bargão

1761 Os Cachimbos dos Séculos XVII e XVIII do Palácio Mesquitela e Convento dos Inglesinhos (Lisboa)

Inês Simão / Marina Pinto / João Pimenta / Sara da Cruz Ferreira / André Bargão / Rodrigo Banha da Silva

1775 "Tomar os fumos da erua que chamão em Portugal erua sancta». Estudo de Cachimbos provenientes da Rua do Terreiro do Trigo, Lisboa

Miguel Martins de Sousa / José Pedro Henriques / Vanessa Galiza Filipe

1787 Cachimbos de Barro Caulínitico da Sé da Cidade Velha (República de Cabo Verde)

Rodrigo Banha da Silva / João Pimenta / Clementino Amaro

1801 Algumas considerações sobre espólio não cerâmico recuperado no Largo de Jesus (Lisboa) Carlos Boavida

1815 Adereços de vidro, dos séculos XVI-XVIII, procedentes do antigo Convento de Santana de Lisboa (anéis, braceletes e contas)

Joana Gonçalves / Rosa Varela Gomes / Mário Varela Gomes

1837 Da ostentação, luxo e poder à simplicidade do uso quotidiano: arqueologia e simbologia de joias e adornos da Idade Moderna Portuguesa Jéssica Iglésias

1849 Os amuletos em Portugal - dos objetos às superstições: o coral vermelho Alexandra Vieira

1865 Cerâmicas de Vila Franca de Xira nos séculos XV e XVI Eva Pires

1879 «Não passa por teu o que me pertence». Marcas de individualização associadas a faianças do Convento de Nossa Senhora de Aracoeli, Alcácer do Sal Catarina Parreira / Íris Fragoso / Miguel Martins de Sousa

1891 Cerâmica de Leiria: alguns focos de produção

Jaqueline Pereira / André Donas-Botto

1901 Os Fornos na Rua da Biquinha, em Óbidos Hugo Silva / Filipe Oliveira

1909 A casa de Pêro Fernandes, contador dos contos de D. Manuel I: o sítio arqueológico da Silha do Alferes, Seixal (século XVI) Mariana Nunes Ferreira

1921 O Alto da Vigia (Sintra) e a vigilância e defesa da costa Alexandre Gonçalves / Sandra Santos

1937 O contexto da torre sineira da Igreja de Santa Maria de Loures Paulo Calaveira / Martim Lopes

1949 A Necrópole do Hospital Militar do Castelo de São Jorge e as práticas funerárias na Lisboa de Época Moderna Susana Henriques / Liliana Matias de Carvalho / Ana Amarante / Sofia N. Wasterlain

1963 SAND - Sarilhos Grandes Entre dois Mundos: o adro da Igreja e a Paleobiologia dos ossos humanos recuperados

Paula Alves Pereira / Roger Lee Jesus / Bruno M. Magalhães

1975 Expansão urbana da vila de Cascais no século XVII e XVIII: a intervenção arqueológica na Rua da Vitória no 15 a 17

Tiago Pereira / Vanessa Filipe

1987 Novos dados para o conhecimento do Urbanismo de Faro em época Moderna Ana Rosa 
1995 Um exemplo de Arqueologia Urbana em Alcoutim: o Antigo Edifício dos CTT Marco Fernandes / Marta Dias / Alexandra Gradim / Virgílio Lopes / Susana Gómez Martínez

2007 Palácio dos Ferrazes (Rua das Flores/Rua da Vitória, Porto): a cocheira de Domingos Oliveira Maia

Francisco Raimundo

2021 As muitas vidas de um edifício urbano: História, Arqueologia e Antropologia no antigo Recreatório Paroquial de Penafiel Helena Bernardo / Jorge Sampaio / Marta Borges

2035 O convento de Nossa Senhora da Esperança de Ponta Delgada: o contributo da arqueologia para o conhecimento de um monumento identitário João Gonçalves Araújo / N’Zinga Oliveira

2047 Arqueologia na ilha do Corvo... em busca da capela de Nossa Senhora do Rosário Tânia Manuel Casimiro / José Luís Neto / Luís Borges / Pedro Parreira

2059 Perdidos à vista da Costa. Trabalhos arqueológicos subaquáticos na Barra do Tejo Jorge Freire / José Bettencourt / Augusto Salgado

2071 Arqueologia marítima em Cabo Verde: enquadramento e primeiros resultados do projecto CONCHA

José Bettencourt / Adilson Dias / Carlos Lima / Christelle Chouzenoux / Cristóvão Fonseca / Dúnia Pereira / Gonçalo Lopes / Inês Coelho / Jaylson Monteiro / José Lima / Maria Eugénia Alves / Patrícia Carvalho / Tiago Silva

2085 Trabalhos arqueológicos na Cidade Velha (Ribeira Grande de Santiago, Cabo Verde): reflexões sobre um projecto de investigação e divulgação patrimonial André Teixeira / Jaylson Monteiro / Mariana Mateus / Nireide Tavares / Cristovão Fonseca / Gonçalo C. Lopes / Joana Bento Torres / Dúnia Pereira / André Bargão / Aurélie Mayer / Bruno Zélie / Carlos Lima / Christelle Chouzenoux / Inês Henriques / Inês Pinto Coelho / José Lima / Patrícia Carvalho / Tiago Silva

2103 A antiga fortificação de Quelba / Khor Kalba (E.A.U.). Resultados de quatro campanhas de escavações, problemáticas e perspectivas futuras Rui Carita / Rosa Varela Gomes / Mário Varela Gomes / Kamyar Kamyad

2123 Colónias para homens novos: arqueologia da colonização agrária fascista no noroeste ibérico Xurxo Ayán Vila / José Mạ . Señorán Martín 


\title{
O CASTRO DE OVIL (ESPINHO), UM QUARTO DE SÉCULO DE INVESTIGAÇÃO (RESULTADOS E QUESTÕES EM ABERTO)
}

Jorge Fernando Salvador ${ }^{1}$, António Manuel S. P. Silva ${ }^{2}$

\begin{abstract}
RESUMO
O castro de Ovil é um pequeno povoado da Idade do Ferro situado no cordão litoral, entre os rios Douro e Vouga. Após diversas fases de trabalhos arqueológicos, entre 1981 e 2006, o seu estudo foi recentemente retomado. O castro possui um sistema defensivo incomum, estruturado apenas por um profundo fosso, parcialmente duplicado, e apresenta uma arquitetura exclusivamente indígena, composta por construções circulares, com e sem vestíbulo, nuclearizadas pela sua orientação para pátios comuns. Os estudos arqueológicos, complementados já por duas datações de radiocarbono, apontam para três horizontes de ocupação deste povoado: a fase IA (séculos IV-III a.C.), a fase IB (sécs. III-II a.C.) e fase II (sécs. II-I a.C., com eventual abandono nos começos do século I).
\end{abstract}

Palavras-chave: Idade do Ferro, «Cultura Castreja», Entre-Douro-e-Vouga, Centro-Norte de Portugal.

\begin{abstract}
Castro of Ovil is a small Iron Age settlement located on the coastal cord between the rivers Douro and Vouga, center-north Portugal. After several campaigns of archaeological excavations, between 1981 and 2006, its study was recently restarted. The site has an uncommon defensive system, structured only by a deep ditch, partially duplicated, and presents an exclusively indigenous architecture, composed of circular constructions, with and without a vestibule, nuclearized by their orientation towards shared yards. Archaeological studies, complemented by two radiocarbon dating, point to three horizons of occupation in the settlement: Phase IA $\left(4^{\text {th }}-3^{\text {rd }}\right.$ centuries BC), Phase IB $\left(3^{\text {rd }}-2^{\text {nd }}\right.$ centuries BC) and Phase II $\left(2^{\text {nd }}-1^{\text {st }}\right.$ centuries BC, with eventual abandonment at the beginning of the first century).
\end{abstract}

Keywords: Iron Age, Castros' culture, Douro-Vouga rivers' region, Center-North Portugal.

\section{INTRODUÇÃO, LOCALIZAÇÃO E CARACTERIZAÇÃO GERAL}

O Castro de Ovil, situado na freguesia de Paramos, concelho de Espinho, distrito de Aveiro, assenta numa pequena colina, com 52,8 metros de cota máxima, encaixada sobre um meandro da ribeira de Riomaior ${ }^{3}$ (Figuras 1 e 2). Situado atualmente a 2 400 metros de distância do mar, o povoado integra o primeiro cordão orográfico que se sucede à planície litoral. Descoberto em 1981, foi objeto de trabalhos arqueológicos, de forma intermitente, entre 1981 e 2006 (Ferreira \& Silva, 1984, 1985; Salvador \& Silva, 2000, 2010; Salvador, Silva \& Sárria, 2005a, 2005b; Silva \& Salvador, 2008). Na atualidade, o sítio integra o Plano de Investigação Plurianual Arqueologia da Idade do Ferro no Entre Douro e Vouga Atlântico (ARQ-EDOV), desenvolvido pelo Centro de Ar-

\footnotetext{
1. Arqueólogo. Câmara Municipal de Espinho; investigador do Projeto ARQ-EDOV; jfmdsal@gmail.com.

2. Arqueólogo. CITCEM - Centro de Investigação Transdisciplinar Cultura, Espaço e Memória (Universidade do Porto); Centro de Arqueologia de Arouca; Coordenador do Projeto ARQ-EDOV; amspsilva@hotmail.com.

3. As coordenadas geográficas de um ponto central são: $40^{\circ} 58^{\prime} 45^{\prime \prime} \mathrm{N} ; 8^{\circ} 37^{\prime} 15^{\prime \prime} \mathrm{W}$ (Carta Militar de Portugal, folha 143, Espinho, escala 1:25 00o).
} 
queologia de Arouca, em colaboração, para este local, com o Município de Espinho (Silva \& alii, 2019). No âmbito deste projeto, em 2019 foram retomadas as escavações arqueológicas no povoado.

Os trabalhos arqueológicos realizados em Ovil caracterizaram um pequeno povoado indígena da Idade do Ferro, composto por estruturas habitacionais circulares definidas por muros de aparelho irregular em xisto. As construções, ocupando uma superfície próxima dos dois hectares, distribuem-se por uma colina de configuração ovalada, em declive suave sobre o seu eixo maior ${ }^{4}$, na qual foram niveladas algumas plataformas para o assentamento proto-histórico. O castro terá as suas origens entre o final do século IV e o início do século III a.C., considerando os materiais recolhidos e uma datação por radiocarbono, e foi ocupado até às primeiras décadas da nossa era, não acusando, praticamente, a presença de materiais romanos, com exceção de algum vasilhame anfórico, a que adiante se fará menção.

A localização do Castro de Ovil, sobre uma área de xisto com alto grau de desagregação veio, talvez, condicionar a organização do seu sistema defensivo, para o qual constitui dispositivo fundamental a ribeira de Riomaior, que contorna as vertentes sul e oeste do sítio, sendo nestes sectores, pela profundidade do seu encaixe original e pela presença de afloramentos rochosos, elemento delimitador e defensivo exclusivo. A norte e a este do povoado, pelo contrário, o menor declive do terreno obrigou à construção de um sistema defensivo particular, constituído por um profundo fosso, com cerca de quinze metros de desnível e uma largura que ronda os oito metros, e que ocorre duplicado em parte da sua extensão.

Este sistema defensivo não parece ter sido complementado por qualquer estrutura de delimitação em pedra ou terra, sendo a este propósito um caso aparentemente singular na região do Entre Douro e Vouga litoral, já que uma parte significativa dos povoados desta época na região apresenta fossos associados a linhas de muralha, como sucede nos castros de Salreu (Estarreja), Ossela (Oliveira de Azeméis) ou nos de Sandim, Monte Murado e Castelo de Gaia, neste último concelho (Silva, 1994, 2005, 2020; Silva \& Pereira, 2010, 2020; Silva $\mathbb{E}$ alii, 2017).

4. De orientação Nordeste-Sudoeste, com cerca de 170 metros de extensão; o eixo Noroeste-Sudeste mede cerca de 114 metros.

\section{FASE IA - OCUPAÇÃO INICIAL DO POVOADO (SÉCULOS IV-III A.C.)}

A fundação do povoado não será anterior, como se disse, ao século IV, uma vez que não se registam quaisquer elementos, nomeadamente no conjunto artefactual exumado, para documentar ocupação anterior. Os primeiros trabalhos arqueológicos, realizados em 1982, junto à antiga Fábrica de Papel Castelo, sob responsabilidade de Carlos Jorge A. Ferreira e Maria Antónia Soares da Silva (Ferreira, Silva, 1982; 1985), não só deixaram a descoberto as primeiras estruturas habitacionais, como abriram caminho, com uma segunda fase de trabalhos entre 1995 e 1999, à caracterização, nesta área (Sector B), de um núcleo habitacional constituído por nove construções (Figuras 2 e 5), no qual, apesar de uma diacronia de ocupação relativamente curta, foi possível definir um esquema de periodização válido para todo o povoado.

Neste sector, o primeiro horizonte de ocupação evidencia-se num fundo de construção de plano subretangular, talhado no afloramento (Estrutura XIII) e em duas construções de planta circular (Est. IX e XI). A localização do povoado numa área de xisto determinou a matéria-prima, já que o xisto local é uma rocha branda e com alto grau de desagregação. As estruturas habitacionais circulares encontram-se definidas por muros de aparelho irregular, feitos com o xisto local, ligando-se com a terra argilosa igualmente local (Figura 5).

No sector F, situado a sudoeste do primeiro, corresponderá a esta fase de ocupação a estrutura circular XXV (Figuras 2 e 3). Os restos de madeira, carbonizada, da ombreira da porta desta construção foram datados por ${ }^{14} \mathrm{C}$, obtendo-se o intervalo de 390-180 calBC, apontando para o século IV a.C. ou, com menor probabilidade, para o séc. III a.C.5. Documentando também esta primeira fase, recolheram-se nas unidades estratigráficas mais antigas deste sector algumas cerâmicas e uma fíbula particularmente interessantes. No primeiro caso, trata-se de

\footnotetext{
5. A data convencional de radiocarbono $(2200 \pm 40)$ foi calibrada, fazendo uso da curva de calibração IntCalo4 (Reimer \& alii, 2004) e do programa OxCal v4.1.03 (Ramsey, 2001), por A. M. Monge Soares, do Instituto Tecnológico e Nuclear, entidade onde foram realizadas as datações e a quem agradecemos a amável e competente colaboração (Salvador \& Silva, 2010: 62-3).
} 
alguns fragmentos de ânfora, pertencentes à forma T-12.1.1.1. (Ramon Torres, 1995), um contentor piscícola, de produção gaditana de influência púnica ${ }^{6}$, cuja circulação pelo litoral atlântico tem vindo a ser enquadrada numa primeira fase de contactos com o noroeste peninsular, compreendidos entre o século IV a.C. e meados do século III a.C. (Ramon Torres, 1995: 233-9; Sáez Romero, 2008: 530-4; Mateo Corredor, 2016: 26). Já a fíbula em bronze, de tipo Sabroso/Ponte 22a, corresponde a uma peça de cronologia ampla, balizada entre a segunda metade do séc. VII e o séc. III a.C. (Ponte, 2006: 218-24), mas que, neste contexto, parece adequar-se bem a uma cronologia da fase inicial do castro.

\section{FASE IB - OCUPAÇÃO INTERMÉDIA (SÉCULOS III-II A.C.)}

A segunda fase de ocupação do castro de Ovil, atribuída aos séculos III e II a.C., foi identificada com clareza nos sectores B, E e F. Entre outros aspetos, parece corresponder, no plano arquitetónico, em diversos sectores, a um momento em que edificações circulares anteriores são dotadas de vestíbulos, podendo também interpretar-se como particularmente típica desta fase uma evidente nuclearização das construções em torno de pátios lajeados comuns.

No sector B, terá ocorrido uma dinâmica de expansão e crescimento do núcleo habitacional, traduzida pela ampliação, com vestíbulos, das estruturas IX e XI, e pela edificação das estruturas circulares X e XII, articuladas com um canal de escoamento de águas pluviais e um pavimento lajeado. Esta nova organização funcional dos conjuntos habitacionais parece privilegiar um modelo arquitetónico no qual a unidade doméstica, com vestíbulo e entrada marcada ao nível do pavimento de circulação, está estrategicamente voltada para uma estrutura circular simples com entrada sobrelevada. Estas associações, observadas no sector B e que poderão indiciar alguma diferenciação funcional de estruturas, configuram um modelo de organização que encontrámos repetido nos sectores $\mathrm{E}$ e $\mathrm{F}$.

No sector E, localizado em área de pendor relativa-

6. Agradecemos a A. M. Sáez Romero a classificação desta peça, por ocasião por workshop «Fenícios \& Púnicos: reflexos do diálogo mediterrâneo-atlântico na arqueologia do noroeste», realizado na Faculdade de Letras da Universidade do Porto em 10 e 13 de dezembro de 2018. mente suave da vertente oeste da plataforma (Figura 4), as intervenções arqueológicas realizadas em 2000 e 2001, vieram revelar um murete de contenção de terras, que define uma plataforma horizontalizada onde se desenvolve um núcleo residencial. Este murete de contenção de terras (Estrutura XVIII) tem por base o afloramento xistoso talhado segundo as linhas de clivagem naturais, resultando num interface vertical rematado por pedra de média e grande dimensão, disposta na horizontal e ligada por abundante argamassa argilosa. Este murete constitui, assim, um elemento estruturador da organização do povoado nesta vertente, definindo e regularizando uma plataforma onde foram detectadas as estruturas circulares XVII e XIX e as casas circulares com vestíbulo XVI, XX e XXI.

Ao nível do modelo de organização deste núcleo devemos registar que as estruturas com vestíbulo XVI e XXI estão estratégica e respetivamente voltadas para as estruturas circulares XIX e XVII, em torno de um pavimento lajeado comum. Estas estruturas circulares, assentes no afloramento previamente regularizado, apresentavam na parede interior um revestimento argiloso, tipo reboco, provavelmente com funções de impermeabilização. A escavação no interior de ambas as estruturas revelou a existência de pisos argilosos de circulação, cobertos por finas camadas de terra escura com pequenos carvões, o que interpretamos como resultado de um momento de incêndio e destruição, com responsabilidade na formação de um intenso derrube que incluía diversos fragmentos de barro, ligeiramente côncavos e espessos, provavelmente provenientes da cobertura das casas.

A estratigrafia observada neste ponto do povoado, a ausência dos materiais mais arcaicos identificados em outros sectores e a tipologia das construções apontam para a integração do núcleo habitacional do sector E na fase IB ocupação do povoado. Esta proposta cronológica surge ainda suportada pela identificação de fragmentos de ânfora que parecem integrar-se no conjunto das produções do séc. III-II a.C. da baía de Cádis7

No sector F, esta fase intermédia de ocupação evidencia as mesmas dinâmicas de crescimento e estra-

7. Agradecemos a J. García Fernández e A. Sáez Romero (Univ. de Sevilla) a classificação destas peças, por ocasião da reunião de trabalho do Proyecto Estrímnides no Museu do Mar (Vigo), em 16.06.2016. 
tégias de distribuição espacial observadas nos outros núcleos habitacionais intervencionados. Verificou-se que a estrutura XXV foi objeto de obras de ampliação, aproveitando parte do muro anterior, resultando numa ampliação da construção de 3,50 para 4,20 metros de diâmetro. Esta beneficiação foi acompanhada pela construção de um vestíbulo, num processo idêntico ao ocorrido no sector B. O processo de crescimento deste conjunto é ainda documentado pela edificação da estrutura circular XXIV, do pavimento lajeado e do muro de traçado retilíneo XXVI. A organização deste núcleo habitacional - estruturado pelo muro XXVI, articulado com o afloramento rochoso - repete os modelos de ocupação planimétrica observados nos outros sectores. A casa com vestíbulo XXV encontra-se voltada para a estrutura circular XXIV, em torno de um pátio lajeado. Este pavimento é formado por pedra de origem xistosa, de média e grande dimensão, disposta na horizontal, e incorporava elementos de dormente de mó giratória em contexto de utilização. $O$ pátio integrava ainda uma cavidade alongada, em tudo idêntica à observada no pavimento lajeado do sector B, que poderá ter servido para retenção de águas ou pia para serventia de animais. A escavação do interior da estrutura XXV permitiu também identificar um piso argiloso com decoração reticulada, feita provavelmente pela impressão de fio torcido, associado a uma lareira definida por uma pequena laje rectangular em xisto colocada na horizontal.

$\mathrm{Na}$ sequência estratigráfica observada no interior das estruturas XXIV e XXV registamos que os últimos níveis de ocupação estavam cobertos por uma fina camada de terra de cor escura, que incorporava numerosos fragmentos de madeira carbonizada, interpretada como estrato de destruição e incêndio. Fragmentos de madeira carbonizada recolhidos no interior da estrutura XXIV foram objeto de uma datação por radiocarbono que aponta para o séc. II a.C. ${ }^{8}$, relacionável, provavelmente, com o abandono deste núcleo habitacional, que não forneceu o material anfórico e as cerâmicas ligeiramente mais «evoluídas» que registamos no horizonte de ocupação da fase seguinte.

8. Ou, com menor probabilidade para a última metade do séc. III ou primeira metade do séc. I a.C. Calibração e comentário à data convencional de radiocarbono (Sac-202O $-2120 \pm 40$ ) por A. Monge Soares (Salvador \& Silva, 2010: $62-3)$.

\section{FASE II - OCUPAÇÃO FINAL (SÉCULOS II-I A.C.)}

A fase final de ocupação do povoado encontra-se muito bem caracterizada, no sector $B$, pela edificação das construções I, II, III, VII e do murete VIII. Mas, também, pelos últimos níveis de ocupação da estrutura XI, a utilização da soleira da estrutura X e, provavelmente, pela ocupação da estrutura XII.

A estrutura circular I está definida, em parte do seu perímetro, por um muro de aparelho irregular sobre um afloramento com acentuada inclinação. Para vencer o desnível e sustentar o muro, a estrutura apresenta, ao nível inferior, um contraforte de contenção de perfil retilíneo, formado por grandes pedras dispostas na horizontal e assentes em estratos anteriores.

A estrutura III revelou-se pelo afloramento xistoso talhado em semicírculo, criando um espaço provavelmente utilizado como habitação. Se a sul e sudeste não se conservaram vestígios de parede, já a oeste e noroeste o afloramento foi cortado, a cerca de o,6o $\mathrm{m}$ do nível do piso, em ângulo reto, formando uma bancada com a largura média de o,40 $\mathrm{m}$, terminando numa depressão semicircular (como um encaixe, que provavelmente sustentaria a parte superior da estrutura), a que se segue o afloramento não desbastado. No interior desta estrutura conservou-se uma lareira, em posição quase central, constituída por pedras definindo um espaço de planta subretangular, e restos de um piso argiloso, decorado por círculos impressos na argila ainda fresca (Ferreira \& Silva, 1982; Salvador \& Silva, 2004: 25).

A casa circular com vestíbulo II está delimitada por um muro relativamente bem cuidado, assente sobre o afloramento, com excepção do braço esquerdo do vestíbulo, que se encontrava apoiado no estrato de abandono e aterro da estrutura IX. No interior deste vestíbulo, adossado à parede da casa, foi também detetado um piso argiloso, de cor avermelhada, decorado por quatro círculos impressos na argila ainda fresca.

Ao nível artecfatual, este horizonte de ocupação do sector B forneceu material anfórico dos tipos Dressel 1, Oberaden 83 e Lusitana da época de Augusto $^{9}$, o que permite supor que o abandono deste núcleo habitacional, e do próprio povoado, terá

9. Classificação de Rui Morais (Universidade do Porto), a quem agradecemos a gentil colaboração. 
ocorrido entre o final do século I a.C. e o início da centúria seguinte.

\section{O ESPÓLIO ARQUEOLÓGICO}

Não se destacando propriamente pela singularidade ou pela presença de objectos exóticos ou valiosos, o espólio recolhido nas intervenções no Castro de Ovil - cujos traços gerais descrevemos na Tabela I - caracteriza-se, pelo contrário, por uma notória homogeneidade, que reflete essencialmente o artesanato e a ergonomia das comunidades autóctones do noroeste atlântico da segunda Idade do Ferro, sendo quantitativamente pouco representativos os materiais importados.

Como é comum em sítios desta natureza, a olaria é dominante entre os restos artefactuais recolhidos. A maior parte deste espólio é constituído por pequenos fragmentos cerâmicos muito rolados e fragmentados, de tonalidades irregulares, cozedura igualmente irregular efetuada geralmente em atmosfera oxidante, e pastas com abundantes elementos não plásticos de dimensão predominantemente média e grande. As peças são maioritariamente montadas ao torno, ainda que o inventário registe um significativo número de peças de fabrico manual.

A quantificação e seriação tipológica da olaria do castro mostra que no conjunto dos perto de 47000 fragmentos recolhidos em todas as campanhas, os morfotipos da fase inicial de ocupação identificados com alguma segurança ascendem a 70 vasilhas, 164 da fase intermédia e 92 da fase final de ocupação ${ }^{10}$, podendo distribuir-se por cinco grandes tipos, que adiante se descrevem.

O elenco formal, que espelha bem - pelos catálogos publicados (Silva, 1986; Martins, 1987; Almeida e Silva, Silva, no prelo) - o trem de cozinha, serviço, transporte e armazenamento das populações da Idade do Ferro, pode ver-se na Fig. 6, que todavia ilustra apenas as cinco formas mais comuns: panelas, potes, púcaros, talhas e vasos de suspensão com asa interior (Salvador \& Silva, 2010: 59-60; no prelo).

10. A distribuição morfológica do material cerâmico decorre da quantificação dos tipos após a sua reconstituição, correspondendo por isso, de um modo geral, ao "Número Mínimo de Indivíduos", embora haja um número superior de bordos, por exemplo, que não permitem decidir, pelas suas dimensões, se pertencem a potes ou a panelas, formas morfologicamente aparentadas ou, quando mais espessos, a potes ou a talhas.
Estas são também as formas que se encontram representadas no Gráfico I, resultante da quantificação dos tipos após a sua reconstituição, correspondendo por isso, de um modo geral, ao Número Mínimo de Indivíduos utilizado nas metodologias mais correntes de contabilização cerâmica (Orton, Tyers \& Vince, 1993: 172; Arcelin, Tuffreau-Libre, 1998).

\subsection{Panelas}

Esta é uma das formas melhor representadas no povoado, devendo corresponder a uma vasilha certamente destinada à cozedura de alimentos ou ao aquecimento de líquidos, o que os recorrentes vestígios de exposição ao fogo nas superfícies exteriores bem evidenciam. Nos contextos da Fase IA de ocupação, os exemplares identificados como panelas (24) apresentam habitualmente perfil em S mais ou menos acentuado e paredes finas, variando o diâmetro da boca entre os 120 e os $160 \mathrm{~mm}$. Na análise das bases observa-se a predominância de fundos rasos, em aresta, com diâmetros que vão dos 110 aos 140 $\mathrm{mm}$. Os exemplares desta forma documentados nas fases IB (45) e II (35) mostram uma clara continuidade formal com os anteriores, se bem que evidenciem uma ampla utilização do torno de oleiro (Figura 6 , números 5 a 10).

As pastas deste tipo de recipiente, de tonalidade exterior entre o castanho e o castanho avermelhado (mais raramente escuras), são arenosas, micáceas e, maioritariamente, de textura relativamente compacta e homogénea. As superfícies, regularizadas, apresentam traços de exposição ao fogo no exterior, como se observou. A qualidade da cozedura das peças, feita maioritariamente em ambiente oxidante, é irregular. A decoração é rara nas panelas, podendo por vezes observar-se uma singela linha incisa (Figura $6, n^{\circ} 6$ ) ou cordão plástico (Figura 6, ํํ8).

\subsection{Púcaros}

Utilizados certamente para o serviço de líquidos, os púcaros constituem um morfotipo algo especializado, cuja representatividade não atinge os $15 \%$ no conjunto total das formas reconhecidas, se bem que pelas suas dimensões e pouca espessura das paredes (originando maior fragmentação), esta forma possa estar algo subrepresentada nas contagens (Figura 6, números 1 a 4). Entre o conjunto olárico da fase IA foram identificados 10 púcaros, caracterizados essencialmente por possuírem perfil em $\mathrm{S}$ de colo alongado e paredes finas. O diâmetro dos bordos 
oscila entre os 90 e os $140 \mathrm{~mm}$. Cerca de um terço dos exemplares analisados são asas com arranque de bordo ou com ligação à parte superior da pança, o que indica a inserção do elemento de preensão no corpo da peça. Já as bases, em aresta ou em bolacha, são horizontais e apresentam diâmetros que variam entre os 65 e os $100 \mathrm{~mm}$. No que toca ao modo de fabrico, observam-se exemplares rodados e outros que indiciam fabrico manual.

Nas fases IB e II contabilizam-se, respetivamente, 19 e 11 púcaros, denotando maior variedade formal, pastas relativamente mais depuradas e acabamentos mais cuidados, servindo de base a diversas composições decorativas estampilhadas. No geral do conjunto, as pastas, de coloração similar à das panelas, são homogéneas, com presença regular de elementos não plásticos de calibre médio; as superfícies externas mostram-se regularizadas ou alisadas, sendo também melhor, por comparação com outros recipientes, a qualidade média de cocção.

\subsection{Potes}

Se bem que a sua morfologia os aproxime das panelas, sobretudo quando de menores dimensões, os recipientes que designamos como potes teriam, aparentemente função diversa, uma vez que não seriam usados para a cozinha, como peças de lume, mas para armazenamento, ou mesmo transporte, de alimentos sólidos e líquidos.

Os efetivos quantificados em cada uma das fases são de 12 potes nos contextos mais antigos, 24 no nível intermédio IB e 8 na fase final de ocupação. Esta forma apresenta geralmente perfil em $\mathrm{S}$ ou, mais raramente, corpo oval, com paredes relativamente finas. Os bordos, lançados para o exterior e por vezes com vestígios de aplanamento interno, exibem diâmetros que oscilam entre os 180 e os $260 \mathrm{~mm}$.

As pastas cerâmicas utilizadas para o fabrico destas vasilhas são de textura compacta e homogénea, geralmente com abundantes partículas de areia e mica. De tonalidade idêntica ao restante vasilhame do castro, as superfícies encontram-se maioritariamente regularizadas ou, menos frequentemente, alisadas. Identificamos exemplares rodados e outros de feitura manual. A decoração parece rara, se bem que para tal possa contribuir a grande fragmentação do conjunto ceramológico.

\subsection{Talhas}

Classificamos como talhas ${ }^{11}$ certos contentores de grandes dimensões, destinados certamente ao armazenamento de produtos alimentares sólidos ou líquidos. As pertencentes à fase IA (19 exemplares), apresentam geralmente bordos lançados para o exterior com superfície interna plana ou côncava e lábio boleado, com uma amplitude de diâmetros que oscilam entre os 260 e os $360 \mathrm{~mm}$. Os fundos, relativamente altos em aresta ou com alargamentos mais ou menos significativos, mostram correntemente diâmetros amplos, próximos de $260 \mathrm{~mm}$. Na fase IB ( 63 exemplares) e final (26) as talhas exibem maior diversidade de perfis, observando-se, nomeadamente, bordos em aba horizontal; variando também as suas dimensões, porventura a indiciar diversidade funcional (Figura 6, números 11 a 14).

As pastas argilosas, de aspeto mais regular ou grosseiro, incluem numerosos elementos arenosos e micáceos de média e grande dimensão. De tonalidade corrente, mostram amiúde variações cromáticas, denunciando a irregularidade da cocção. $\mathrm{O}$ aspeto das superfícies é por vezes rugoso no exterior. A ornamentação surge com alguma frequência. Nos contextos iniciais com recurso a diferentes técnicas e motivos - SS, triângulos rematados nos ângulos por círculos, triângulos internamente preenchidos por linhas paralelas incisas, linhas cruzadas em xadrez, punções circulares ao nível do bordo, etc.; nas fases IB e II, predominando decoração geométrica incisa.

\subsection{Vasos de Suspensão}

Estes vasos destinavam-se à cozinha e eram suspensos sobre a lareira, função confirmada pela sua morfologia e pela sistemática presença de sinais de exposição ao fogo no exterior das peças.

Nos horizontes de ocupação inicial foram exumadas cinco asas interiores de secção circular aplicadas na parte superior das paredes com os arranques em plano horizontal. Na fase IB temos 13 exemplares e na final 12 unidades, o que nos permitiu reconstituir graficamente recipientes de grande dimensão, largos e abertos (diâmetro do bordo entre os 400 e os $500 \mathrm{~mm}$.), com forma em tronco de cone relativamente baixo, de paredes direitas ou ligeiramente arqueadas, espessando para o bordo, e fundo raso.

11. Preferimos esta designação, tradicional no nosso país, à alternativa dolia, própria dos ambientes romanizados que não encontramos em Ovil. 
Na panóplia olárica de Ovil surgiu apenas um exemplar de um vaso de "asa em orelha», em contexto de derrube.

\subsection{Outros tipos cerâmicos}

Além das formas acima elencadas, registam-se outras, com representação bastante mais reduzida, que optámos por não descrever por economia de texto, o mesmo fazendo com as louças importadas, reduzidas, praticamente, aos materiais anfóricos que já foram mencionados. Devemos no entanto registar, no que respeita às produções indígenas, a presença de peças que identificámos como alguidares com vertedouro, cântaros e, em particular, uma forma muito específica que é uma assadeira retangular (Salvador, Silva, no prelo).

Passando aos itens cerâmicos não ligados à alimentação, devemos destacar, além de numerosos cossoiros discoidais e alguns pesos de tear, destinados respetivamente à fiação e à tecelagem, a identificação de um conjunto de pesos de maiores dimensões, feitos em barro, inicialmente interpretados como ligados à tecelagem mas que entretanto, em resultado de evidências mais claras, podemos, com maior segurança, classificar como pesos de fixação das coberturas das construções (Figura 7).

De facto, os níveis de derrube detetados no interior das estruturas XVII e XIX (sector E) continham uma grande quantidade de fragmentos de barro, ligeiramente côncavos e espessos, em tudo idênticos aos exumados no interior de algumas casas do sector B. Posteriormente, a escavação da estrutura XXV (sector F) revelou, numa espessa camada de abandono e derrube da construção, 16 destes pesos em barro, mais completos que os anteriores. Apresentam um formato ovalado, perfuração circular na extremidade e cerca de 3,3 kg. de peso, em média. Considerando que a cobertura das estruturas seria feita utilizando o colmo ou outro elemento vegetal, eventualmente reforçado por barro, tornava-se necessário, face à exposição aos fortes ventos marítimos, o recurso a elementos cujo peso assegurasse a integridade da cobertura, função desempenhada por estes pesos, amarrados com cordas e que ficariam suspensos, ou pousados, sobre a cobertura vegetal (Salvador \& Silva, 2010: 61).

A utilização de objetos classificáveis como pesos de cobertura ou "pedras de colmo", na maior parte dos casos feitos em pedra, está registada em muitos castros do Noroeste, se bem que não tenham merecido particular atenção dos investigadores portugueses, ao contrário da bibliografia galega (López-Cuevillas, 1988 [1953]: 119; Calo Lourido, 1993: 107-8; Arias Vilas \& Durán Fuentes, 1996: 69-70). Na região em que se insere o castro de Ovil documentam-se pesos de cobertura, feitos em pedra, pelo menos no Castro de Salreu, Estarreja (Silva \& alii, no prelo) e no Castro de Valinhas, Arouca, onde foram localizados, junto a uma casa redonda, sete exemplares, em xisto, com pesos que variam entre 2,4 e $7,0 \mathrm{~kg}$. (Salvador \& Silva, 2010: 61).

\subsection{Outros materiais}

Para além de alguns objetos metálicos, pouco frequentes, dos quais destacamos algumas fíbulas e duas pontas de lança em liga de ferro, exumaram-se no Castro de Ovil diversos materiais feitos em pedra. Trata-se, essencialmente, de mós, seixos talhados lateralmente para serem usados como pesos (presumivelmente de redes de pesca) e, em ocorrências mais raras, machados, lâminas, amoladores e outros. No que se refere às mós, localizaram-se quatro exemplares de rebolo ou vai-vém, em granito, e um número muito maior de fragmentos de dormentes e moventes de mós giratórias, merecendo nota a circunstância de alguns pavimentos lajeados, da fase intermédia de ocupação (IB), incorporarem, in situ, elementos dormentes em contexto de uso.

\section{NOTAS CONCLUSIVAS}

Contando já com uma significativa área escavada, o Castro de Ovil destaca-se no panorama regional, por ser um dos poucos que não acusa, ao nível arquitetónico, como no artefactual, evidência de "romanização»" ${ }^{12}$. Ou seja, observamos um povoado indígena com construções integralmente de plano curvilíneo ${ }^{13}$, sem a mínima evidência do uso de telha cerâmica e cuja ergologia, ao longo dos 350 ou 400 anos que estimamos para a sua ocupação, é também claramente autóctone, salvo talvez um par de fíbulas em bronze e, certamente, as contas de colar em pasta vítrea e os restos de material anfórico,

\footnotetext{
12. O mesmo sucede no vizinho Castro de Salreu (Almeida e Silva \& alii, neste volume), mas com menor área escavada e escassa documentação das estruturas domésticas.

13. Com a única exceção da Estrutura «rupestre» XIII, do sector $\mathrm{B}$, que pertence à fase inicial de ocupação.
} 
aliás, em pequena quantidade, que documentam contactos e trocas com ambientes forâneos.

Se bem que escassamente representadas em Ovil, estas articulações, comerciais e simbólicas, com horizontes culturais e económicos meridionais, primeiro de enquadramento púnico, e depois já na esfera das dinâmicas comerciais estimuladas por Roma, resultarão, primordialmente, da implantação litoral do povoado, e nomeadamente da sua proximidade à antiga Lagoa de Ovil (atual Barrinha de Paramos/ Esmoriz) aberta ao mar até aos séculos XII/XIII, formando uma enseada que permitia a atracagem de navios.

Mas, regressando à arquitetura e ao desenho «urbano" deste aglomerado, a leitura estratigráfica precisa proporcionada pelas escavações, permitiu afinar aspetos de grande interesse na arquitetura castreja, como a cronologia da tão disseminada "moda» da ampliação das construções com vestíbulos colaterais às entradas. Por outro lado, contrariando a imagem aparente, proporcionada por algumas plantas de castros, de uma ocupação do espaço intensa e cuja organicidade parece alheia a qualquer organização social ou funcional, as escavações de Ovil demonstraram um padrão de organização indígena, social ou vicinal, percebido já em outros castros mas que aqui se patenteia como típico da fase intermédia (séculos III-II a.C.). Referimo-nos à nuclearização funcional (que prescinde dos muros delimitadores das "casas familiares» alargadas que se observam nas grandes citânias como Sanfins ou Briteiros) que articula e orienta para um pátio lajeado comum construções com e sem vestíbulo; pátio assumido como elemento higienizador, vertebrador da circulação interna na aldeia e, certamente, convivial, não fossem as mós convenientemente inseridas nesse chão comum, a sugerir partilhas do trabalho e da vida.

Mais que as razões ou circunstâncias fundacionais do povoado, importam-nos em Ovil as condições e a cronologia do seu abandono, provavelmente pacífico, já discutidas em trabalho anterior (Salvador \& Silva, 2010: 63-4). Ao tempo do primeiro imperador, com a região pacificada e sob domínio das legiões, a comunidade fundadora e residente no castro Ovil (certamente menos de um milhar de almas) terá arrumado os pertences, esvaziado as casas e transportado alfaias e animais para nova morada. E não só os castellani de Ovil. Pela mesma época, mais década menos década, cremos que também os de Salreu, e provavelmente os de outros pequenos castros, tomaram, ou foram impelidos a tomar, a mesma decisão.

Se nestas movimentações de gentes e meios de produção há mão de Roma, ou simples fenómeno de sinecismo, motivado não já por necessidade de defesa congregada, mas por dinâmicas económicas e sociais que, porventura, atraíssem a certos povoados as populações dos vizinhos, é questão fulcral para a história da região e do noroeste castrejo-romano (Salvador \& Silva, idem, ibid.), que aqui não podemos discutir, mas para a qual a investigação sobre o pequeno castro de Ovil poderá dar um contributo não despiciendo.

\section{BIBLIOGRAFIA}

ALMEIDA e SILVA, Sara; SILVA, António Manuel S. P. [no prelo] - Breves considerações sobre a cerâmica da Idade do Ferro do Castro de Salreu (Estarreja, Aveiro). Atas do Congresso Internacional de Cultura Castreja. Santa Maria da Feira.

ARCELIN, Patrice; TUFFREAU-LIBRE, Marie, dir. (1998) - La quantification des céramiques. Conditions et protocole. Actes de la table-ronde (...) du Mont Beuvray. Glux-enGlenne: CAE (Bibracte, 2).

ARIAS VILA, Felipe ; DURÁN FUENTES, M. C. (1996) Museo del Castro de Viladonga - Castro de Rei, Lugo. S.l.: Xunta de Galicia.

CALO LOURIDO, Francisco (1993) - A Cultura Castrexa. Vigo: A nossa terra.

FERRER-ALBELDA, Eduardo; GARCÍA FERNÁNDEZ, Francisco; SÁEZ ROMERO, Antonio; RODRÍGUEZ-CORRAL, Javier; ALBUQUERQUE, Pedro (2019) - A Rota do Estanho: Gadir e o Comércio Fenício no Noroeste da Ibéria (Séculos IV - II a.C.). Revista Hélade, 5: 2. Rio de Janeiro, pp. 83-117. doi: 10.22409/rh.v5i2.42485

FERREIRA, Carlos J. A.; SILVA, Maria A. (1982) - Castro de Ovil, Paramos, Espinho. Relatório de trabalhos arqueológicos. Lisboa, relatório datilog.

FERREIRA, Carlos J. A.; SILVA, Maria A. (1984) - Distrito de Aveiro. Espinho. Castro de Ovil. Informação Arqueológica, 4 (1981). Lisboa, pp. 41-43.

FERREIRA, Carlos J. A.; SILVA, Maria A. (1985) - Espinho: Castro de Ovil. Informação Arqueológica, 5. (1982-83). Lisboa, pp. 38-39.

LÓPEZ CUEVILLAS, Florentino (1988) - La civilización céltica en Galicia. Madrid: Istmo [ed. orig. 1953].

MARTINS, Manuela (1987) - A cerâmica proto-histórica do Vale do Cávado: tentativa de sistematização. Cadernos de Arqueologia, série 2, nº 4. Braga, pp. 35-77.

MATEO CORREDOR, Daniel (2016) - Comercio anfórico y relaciones mercantiles en Hispania Ulterior (s. II a.C. - II d.C.). Barcelona: Universitat de Barcelona. 
ORTON, Clive; TYERS, Paul; VINCE, Alan (1993) - Pottery in archaeology. Cambridge: Cambridge Univ. Press

PONTE, Salete da (2006) - Corpus Signorum das Fíbulas Proto-Históricas e Romanas de Portugal. Coimbra: Caleidoscópio.

RAMON TORRES, Joan (1995) - Las ánforas fenicio-púnicas del Mediterráneao central y ocidental. Barcelona: Universitat de Barcelona.

RAMSEY, Christopher Bronk (2001) - Development of the Radiocarbon calibration program OxCal. Radiocarbon. 43 (2A). (Proceedings of the $17^{\text {th }}$ International Radiocarbon Conference). Cambridge, pp. 355-63. https://doi.org/1o. 1017/Soo33822200038212

REIMER, Paula J.[et. al.] (2004) - IntCalo4 Terrestrial Radiocarbon Age Calibration, o-26 cal Kyr BP. Radiocarbon. 46 (3), Tucson, pp. 1029-58. Disp. em https://journals.uair. arizona.edu/index.php/radiocarbon/article/view/4167

SÁEZ ROMERO, Antonio M. (2008) - La producción cerámica en Gadir en época tardopúnica (siglos -III/-I). Oxford: Archaeopress; Universidad de Cádiz.

SALVADOR, Jorge F.; SILVA, António Manuel S. P. (2000) - Da descoberta do Castro de Ovil à criação de um Gabinete de Arqueologia. Al-Madan. 2 Série, 9. Almada, pp. 169-73.

SALVADOR, Jorge F.; SILVA, António Manuel S. P. (2004)O Castro de Ovil e o povoamento da região de Espinho da proto-história à romanização (OVESP). Relatório Final de Trabalhos Arqueológicos. Espinho: Câmara Municipal, policop.

SALVADOR, Jorge F.; SILVA, António Manuel S. P. (2010) O Castro de Ovil (Espinho, um povoado da Idade do Ferro. In PINTO, Filipe M. S. (coord.) - Arqueologia da Terra de Santa Maria: balanços e perspectivas. Santa Maria da Feira: Liga dos Amigos da Feira: pp. 53-73.

SALVADOR, Jorge F.; SILVA, António Manuel S. P. (no prelo) - Cerâmica da Idade do Ferro do Castro de Ovil (Espinho, Aveiro). Atas do Congresso Internacional Cultura Castreja. Santa Maria da Feira.

SALVADOR, Jorge F.; SILVA, António Manuel S. P.; SÁRRIA, Carlos A. (2005a) - O Centro Interpretativo do Castro de Ovil (Espinho): a construção de um espaço de memória. In JORGE, V. O. (coord.) - Conservar Para Quê? 8. ${ }^{\underline{a}}$ Mesa-redonda de Primavera. Porto-Coimbra: Fac. de Letras da Universidade do Porto; CEAUCP, pp. 303-26.

SALVADOR, Jorge F.; SILVA, António Manuel S. P.; SÁRRIA, Carlos A. (2005b) - O Centro Interpretativo do Castro de Ovil (Espinho). In SILVA, António Manuel S. P. (coord.) - Cartas Arqueológicas: do inventário à salvaguarda e valorização do património. Actas das Jornadas realizadas em Arouca em 2004. Arouca: Câmara Municipal, pp. 61-68.

SILVA, António Manuel S. P. (1994) - Proto-história e Romanização no Entre Douro e Vouga Litoral. Elementos para uma avaliação crítica. Dissertação de Mestrado apresentada à Faculdade de Letras da Universidade do Porto.
SILVA, António Manuel S. P. (2005) - Povoamento proto-histórico no Entre Douro e Vouga Litoral: a estruturação do habitat. I - Arquitectura dos castros. In Castro, um lugar para habitar. Colóquio [Cadernos do Museu, 11]. Penafiel: Museu Municipal, pp. 167-188.

SILVA, António Manuel S. P. (2020) - O Castelo de Gaia, um sítio arqueológico excecional e um valor cultural a potenciar. In: Santa Casa da Misericórdia do Porto (coord.) Pessoa(s), Arte, Benemerência. IV Congresso de História da Santa Casa da Misericórdia do Porto. Porto: SCMP, p. 51936 , ilust. em extra-texto.

SILVA, António Manuel S. P.; PEREIRA, Gabriel R. (2010) - Povoamento proto-histórico na fachada atlântica do Entre Douro e Vouga. Paleoambientes e dinâmica cultural. In BETTENCOURT, A.; ALVES, M.; MONTEIRO-RODRIGUES, S. (eds.) - Variações paleoambientais e evolução antrópica no Quaternário do Ocidente Peninsular. S.l.: APEQ/ CITCEM, pp. 189-203.

SILVA, António Manuel S. P.; PEREIRA, Gabriel R. (2020) - Walls and Castros. Delimitation structures in the Proto-historic settlements of Entre Douro and Vouga region (Center-North of Portugal). In DELFINO, Davide; COIMBRA, Fernando; CARDOSO, Daniela; CRUZ, Gonçalo Late Prehistoric Fortifications in Europe: Defensive, symbolic and territorial aspects from the Chalcolithic to the Iron Age. Proceedings of the International Colloquium 'FortMetalAges', Guimarães, Portugal. Oxford: Archaeopress, pp. 215-28.

SILVA, António Manuel S. P.; PEREIRA, Gabriel R.; ALMEIDA E SILVA, Sara; LEMOS, Paulo (2017) - Uma aldeia de há dois mil anos. Um sítio arqueológico e a sua investigação. Terras de Antuã. Histórias e Memórias do Concelho de Estarreja. 11. Estarreja, pp. 15-29.

SILVA, António Manuel S. P.; PEREIRA, Gabriel; LEMOS, Paulo; ALMEIDA E SILVA, Sara (no prelo) - O Castro de Salreu (Estarreja): um povoado da Idade do Ferro nos limites meridionais da "cultura castreja". In Atas do I Ciclo de Conferências do Monte Padrão. Santo Tirso.

SILVA, António Manuel S. P.; SÁ, Edite M.; SALVADOR, Jorge F.; LEMOS, Paulo; ALMEIDA e SILVA, Sara (2019) - O castro de Salreu, um dos povoados proto-históricos atlânticos do Entre Douro e Vouga. Terras de Antuã. Histórias e Memórias do Concelho de Estarreja. 13. Estarreja, pp. 24-44.

SILVA, António Manuel S. P.; SALVADOR, Jorge F. (2008) - Castro de Ovil (Espinho, Aveiro). In VILAÇA, Raquel; CUNHA-RIBEIRO, João - Das primeiras ocupações humanas à chegada dos Romanos à Beira Litoral/From the first human occupations to the arrival of the Romans to Beira Litoral. Tomar: CEIPHAR, pp. 173-81.

SILVA, Armando C. F. (1986) - A Cultura Castreja no Noroeste de Portugal. Paços de Ferreira: Câmara Municipal; Museu Arqueológico da Citânia de Sanfins. 


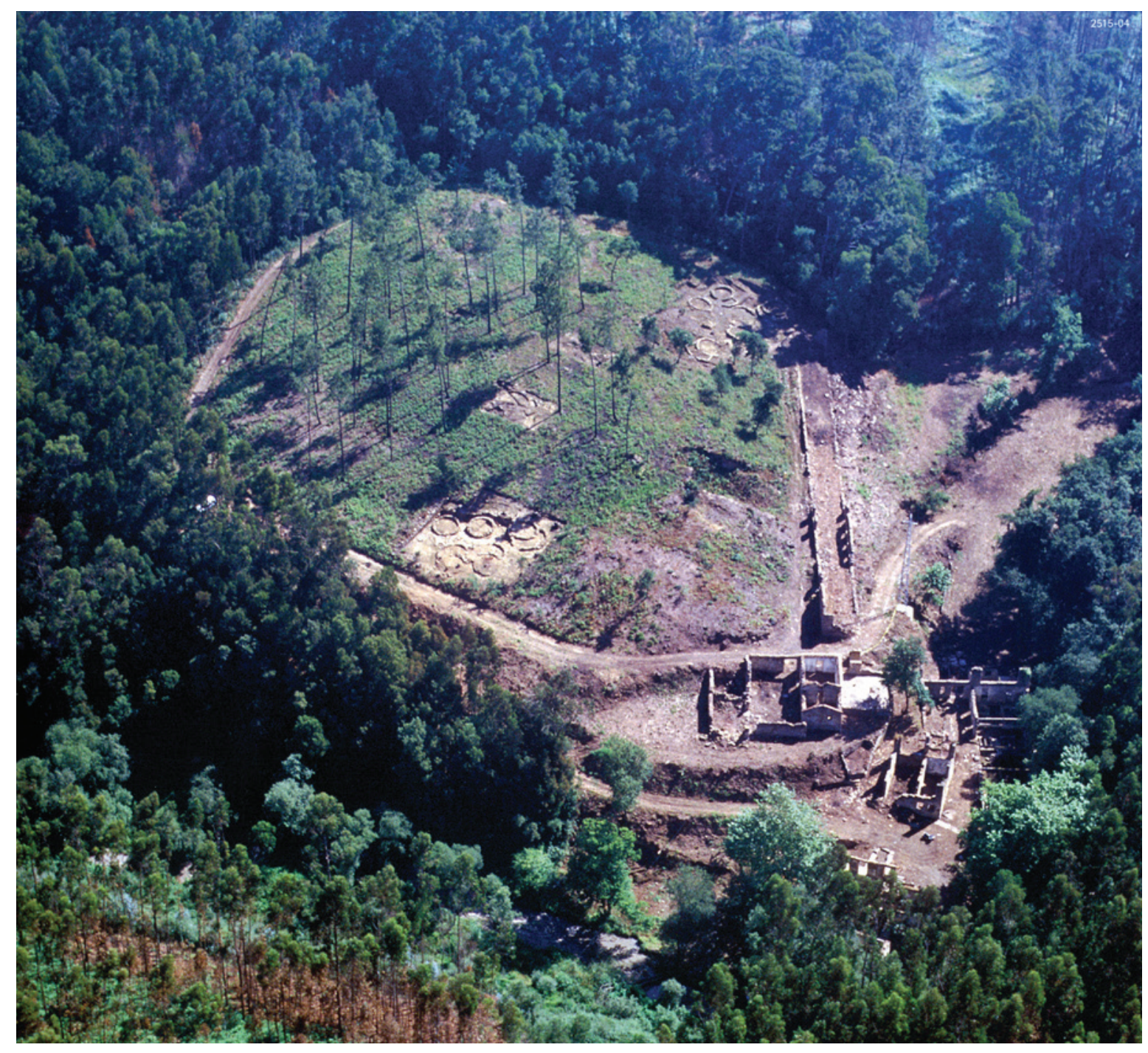

Figura 1 - Castro de Ovil, vista aérea. (Foto: J. Ferrand/C. M. Espinho) 


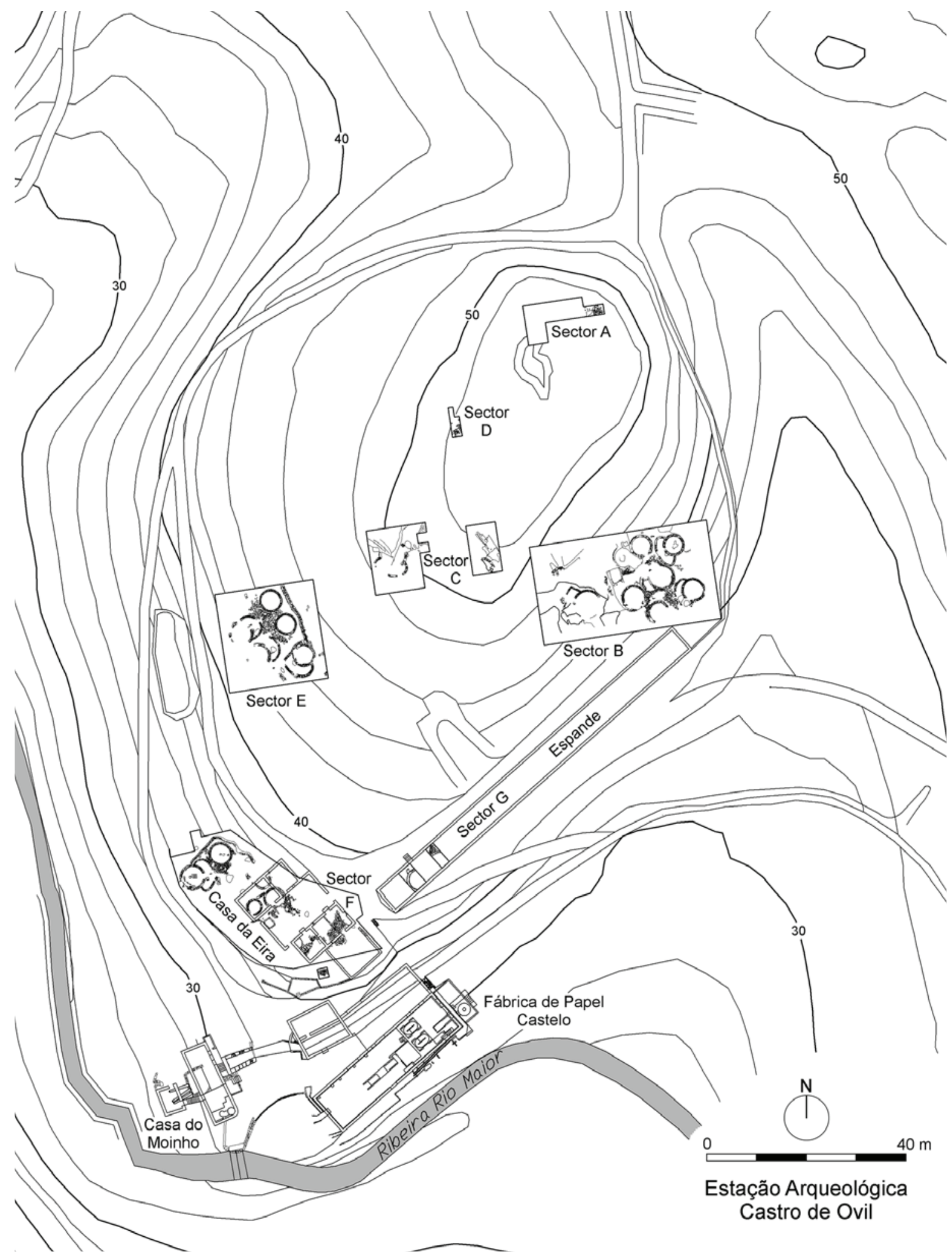

Figura 2 - Planta geral da estação arqueológica do Castro de Ovil (Serviço de Arqueologia/C. M. Espinho). 


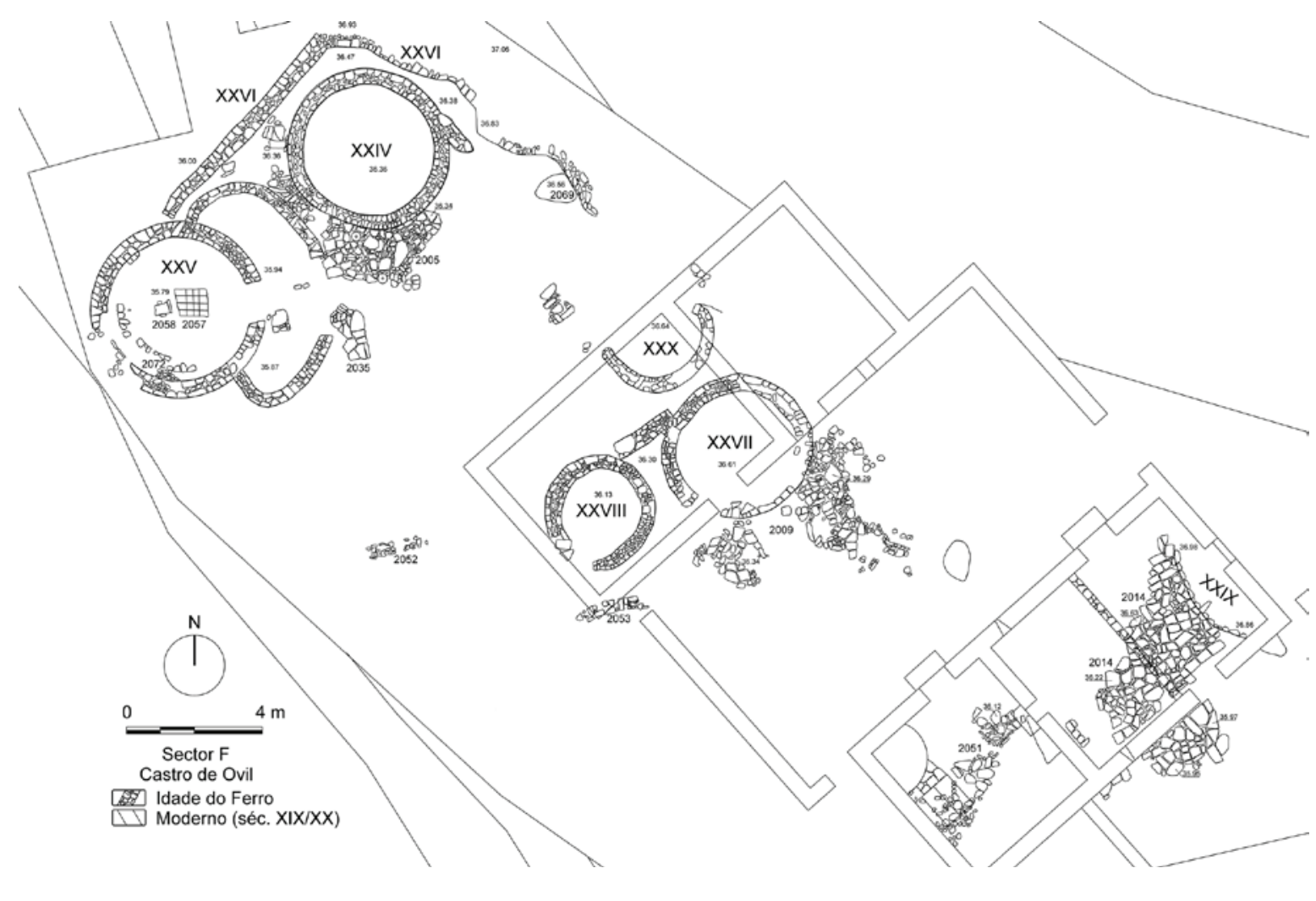

Figura 3 - Castro de Ovil. Planta do sector F (Serviço de Arqueologia/C. M. Espinho).

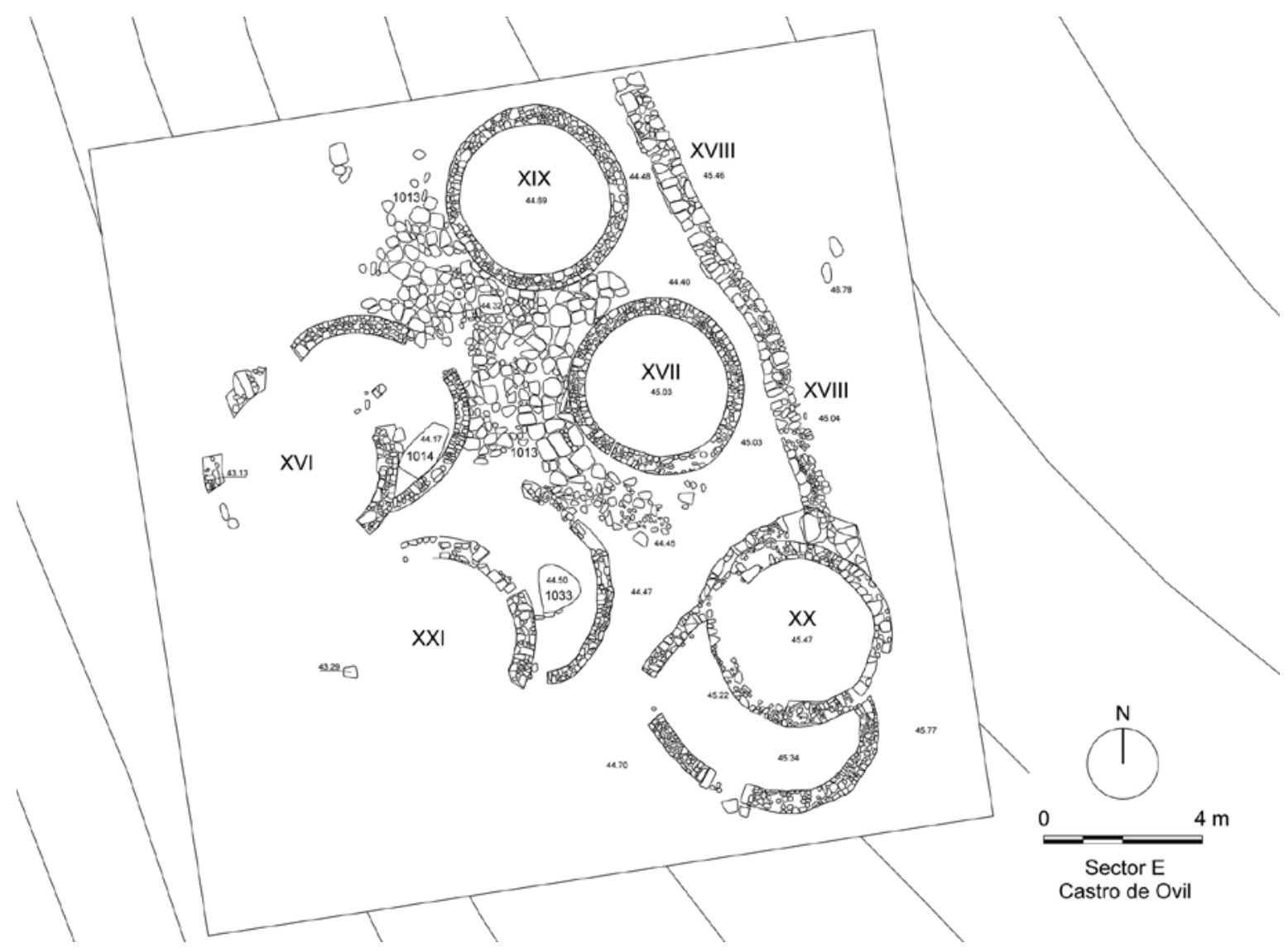

Figura 4 - Castro de Ovil. Planta do sector E (Serviço de Arqueologia/C. M. Espinho). 


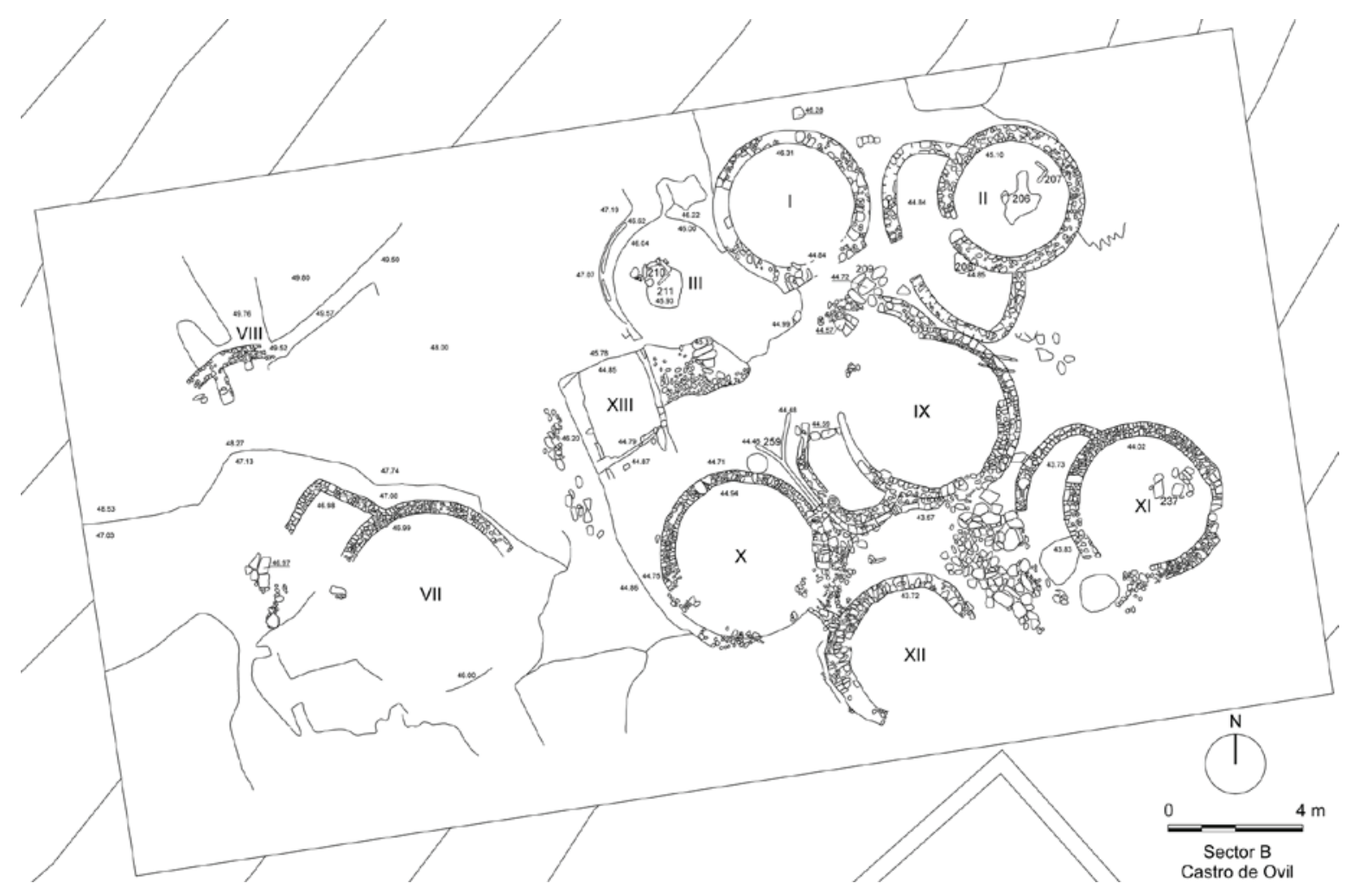

Figura 5- Castro de Ovil. Planta do sector B (Serviço de Arqueologia/C. M. Espinho).

\begin{tabular}{|c|c|c|c|c|}
\hline \multirow{2}{*}{ FASES } & \multicolumn{3}{|c|}{ CERÂMICA } & \multirow{2}{*}{ OUTROS MATERIAIS } \\
\hline & Modelação & Formas & Decoração & \\
\hline $\begin{array}{l}\text { Inicial (IA) } \\
\text { IV-III aC }\end{array}$ & $\begin{array}{c}\text { Cerâmica manual e } \\
\text { modelada a torno }\end{array}$ & $\begin{array}{l}\text { Homogeneidade do } \\
\text { elenco formal de panelas, } \\
\text { potes e vasos de } \\
\text { suspensão }\end{array}$ & $\begin{array}{l}\text { Homogeneidade nos } \\
\text { motivos }\end{array}$ & $\begin{array}{c}\text { Contas de colar } \\
\text { (pasta de vidro) } \\
\text { Fíbula tipo Sabroso } \\
\text { Ânfora gaditana de influência } \\
\text { púnica T-12.1.1.1. }\end{array}$ \\
\hline $\begin{array}{c}\text { Intermédia (IB) } \\
\qquad\|I-\| \mathrm{aC}\end{array}$ & $\begin{array}{l}\text { Mais cerâmica montada } \\
\text { a torno, ainda que se } \\
\text { registe cerâmica manual }\end{array}$ & \multirow{2}{*}{$\begin{array}{l}\text { Tendência para uma } \\
\text { variedade formal de } \\
\text { púcaros e talhas }\end{array}$} & \multirow{2}{*}{$\begin{array}{c}\text { Tendência para } \\
\text { alguma complexidade } \\
\text { na organização } \\
\text { decorativa. }\end{array}$} & $\begin{array}{l}\text { Contas de colar } \\
\text { (pasta de vidro) } \\
\text { Ânfora gaditana }\end{array}$ \\
\hline $\begin{array}{c}\text { Final (II) } \\
\text { II aC - inic. I dC }\end{array}$ & $\begin{array}{l}\text { Presença residual de } \\
\text { cerâmica manual }\end{array}$ & & & $\begin{array}{c}\text { Contas de colar } \\
\text { (pasta de vidro) } \\
\text { Ânforas - Dressel 1; Oberaden } \\
\text { 83; Lusitana (Augusto) }\end{array}$ \\
\hline
\end{tabular}

Tabela I - Quadro-síntese do espólio arqueológico do Castro de Ovil, por fases de ocupação. 


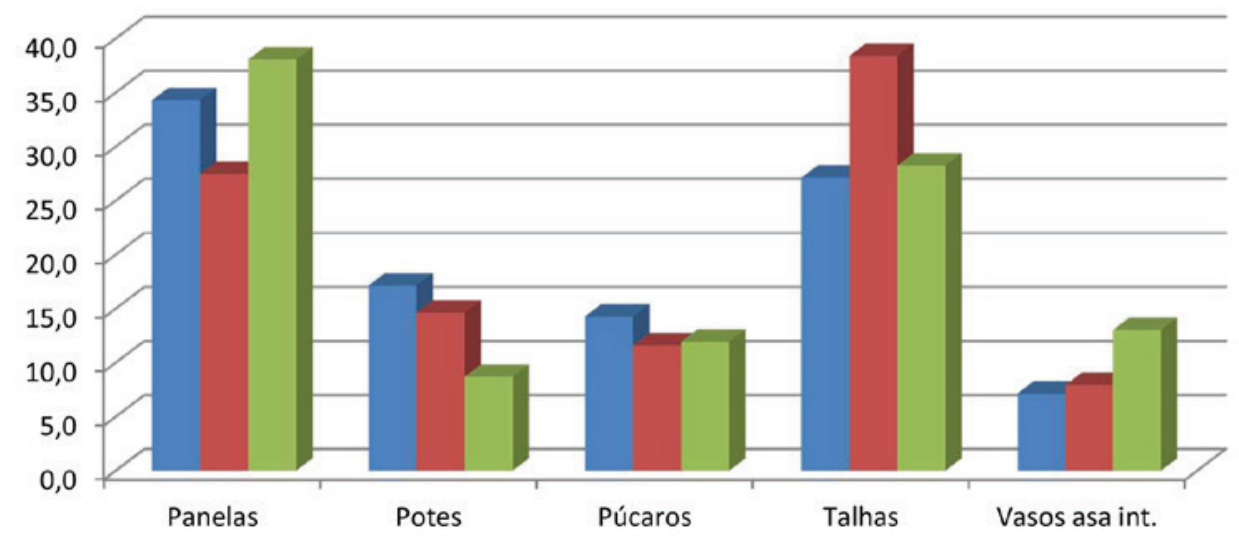

Fase IA

sécs. IV-III aC

- Fase IB

sécs. III-II aC

- Fase II

sécs. II-I aC

Gráfico I - Representação das principais formas por fases de ocupação (valores percentuais). 


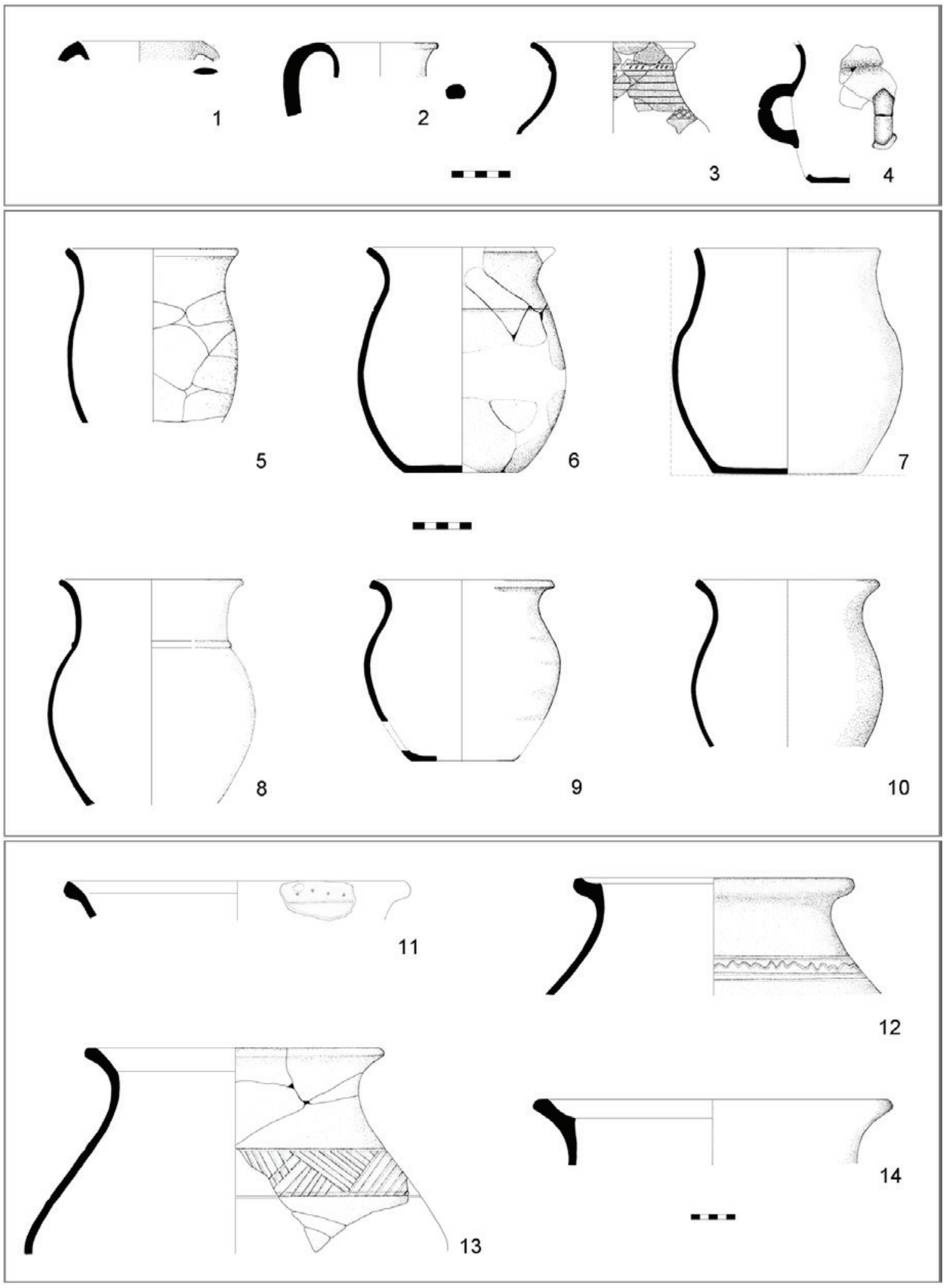

Figura 6 - Formas cerâmicas indígenas do Castro de Ovil, identificadas por grandes tipos, número de inventário e fases de ocupação. Púcaros: 1 - 2001 (IA); 2 -1523 (IB); 3-250 (II); 4-106 (II); Panelas: 5-2161 (IA); 6 - 422 (IA); 7-1562 (IB); 8 -420 (II); 9 - 257 (II); 10 - 2 (II); Talhas: 11 - 2169 (IA); $12-1564$ (IB); $13-374$ (IB); 14 - 57 (II). Desenho: Serviço de Arqueologia/C. M. Espinho. 


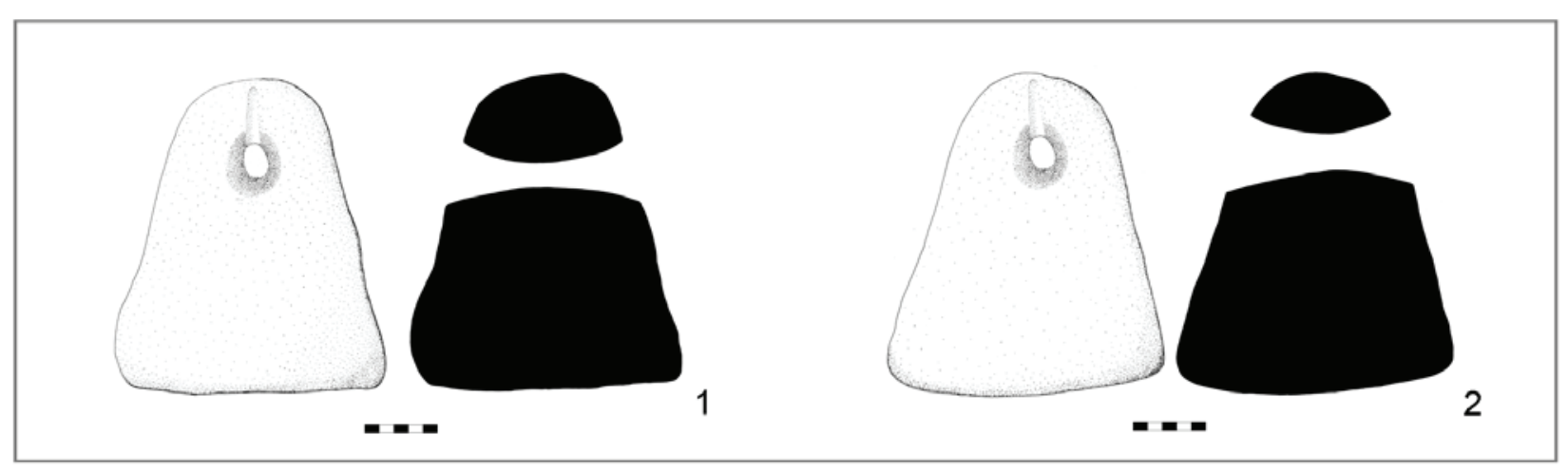

Figura 7 - Castro de Ovil. Pesos de cobertura em argila. 1 - 2058 (fase IB); 2 - 2056 (fase IB). Desenhos: Serviço de Arqueologia/ C. M. Espinho.

1110 



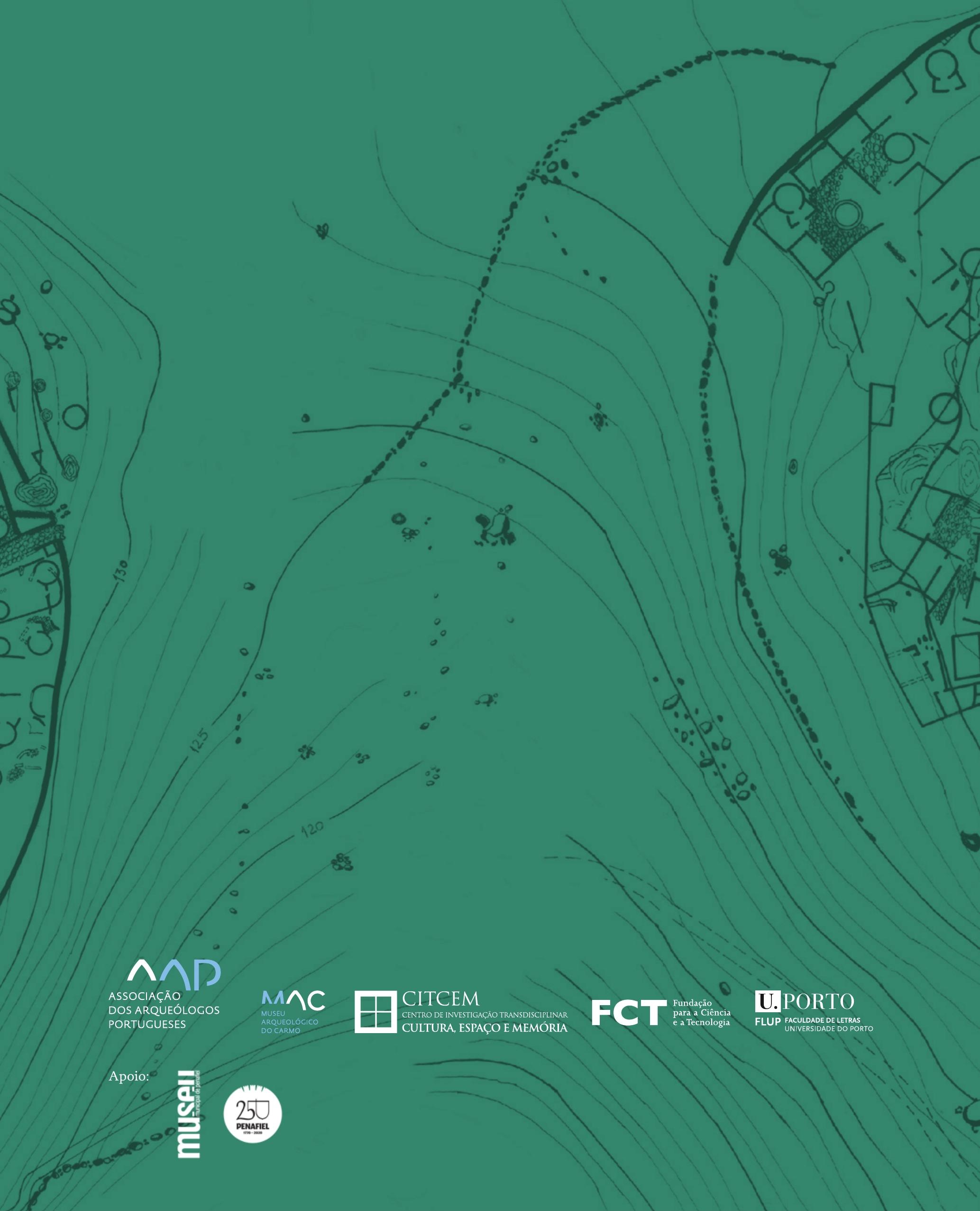

